\title{
Le torri colombaie nel paesaggio di pianura. Analisi tipologiche, rilievo architettonico per la conoscenza
}

\author{
Ivana Passamani \\ Matteo Pontoglio Emilii
}

Abstract

La torre colombaia è un elemento architettonico distintivo della pianura padana. Studiare questo landmark consente di individuare un segno comune a molti paesaggi europei ed extraeuropei legato all'allevamento dei volatili, che oltre che per l'alimentazione erano utilizzati come portatori di messaggi ma anche come produttori di fertilizzante. Possiamo quindi definire il colombo come un anello di un'economia agricola circolare, e la torre colombaia come simbolo di un processo economico sostenibile, in cui nulla era casuale o andava sprecato. La ricerca indaga il fenomeno delle torri colombaie nel paesaggio della pianura, per individuarne le connotazioni principali e gli elementi formali. In particolare, nel territorio della pianura orientale si palesa il costume di allevare anche i passeri, per poter utilizzare le carni nella preparazione dello spiedo. Nascono quindi anche le torri passerere, strutture analoghe alle colombaie. La bibliografia sul tema offre qualche monografia, testi o articoli e alcuni studi. Facendo riferimento ad alcuni trattati d'agricoltura storici si evidenziano le caratteristiche costruttive suggerite per le architetture atte a questi scopi. La metodologia di ricerca prevede più fasi: ricerca storico-bibliografica; schedatura; rilievo di esempi campione; sistematizzazione in tavole sinottiche. Obiettivi: catalogare i sistemi colombaie/passerere; individuare gli elementi connotativi; identificare i riferimenti storico-architettonici adottati.

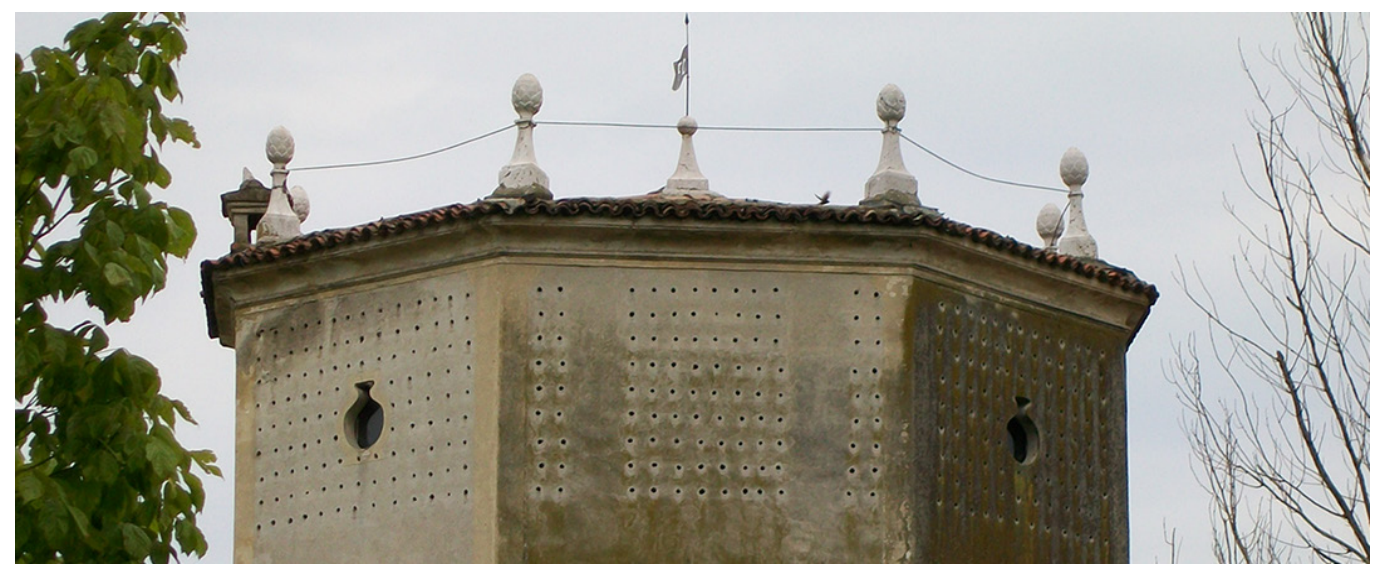




\section{L'oggetto di studio}

Pur nella sua specificità, la torre colombaia nella esperienza visiva del paesaggio della pianura è parte integrante e identificativa della cascina, "il nuovo centro aziendale della grande affittanza capitalistica, che diviene il centro di riorganizzazione di tutto il paesaggio agrario della Pianura Padana" [Sereni 1987, p. 338] [I].

È un elemento architettonico che appartiene alla storia dell'uomo in quanto l'allevamento dei volatili è stato praticato fin dall'antichità. Si possono infatti distinguere torri colombaie negli skyline e nelle pianure di svariati paesaggi europei ed extraeuropei, ed è significativo pensare che per pochi altri animali l'uomo abbia progettato edifici specializzati per l'allevamento, che al tempo stesso esprimono caratteri decorativi e formali peculiari.

La varietà di soluzioni presenti nel panorama internazionale, infatti, fa pensare che il pensiero progettuale non si sia limitato alla ricerca delle migliori soluzioni funzionali, ma abbia anche cercato effetti decorativo-percettivi sempre originali ma coerenti con le risorse locali.

Una dimostrazione dell'importanza che il colombo rivestiva nel mondo greco risiede nel fatto che nell'antica Attica fosse un uccello mitologico. I suoi significati simbolici, del resto, attraversano popoli e religioni.

I piccioni erano usati per l'alimentazione ma anche come messaggeri; inoltre lo sterco prodotto era considerato il miglior concime per l'agricoltura, come testimonia Varrone [Traglia 1974, p. 828].

Possiamo definire le colombere come edifici-macchina, in quanto ripetono le medesime caratteristiche distributive e organizzative, funzionali alla vita e all'allevamento dell'animale ospitato. Nessun dettaglio o elemento è casuale, ma rende possibile il ciclo giornaliero di soggiorno del volatile e il soddisfacimento delle sue esigenze.

Gli edifici sono dotati di un'unica porta per l'ingresso dell'allevatore, le finestre alla cartaginese ed un particolare tipo di intonaco molto liscio impediscono a serpenti o altri animali di entrare; i piccoli fori che bucano la muratura, detti occhi, consentono ai colombi l'ingresso e l'uscita mentre piccole mensole a sbalzo o cornici continue modanate offrono un piano di appoggio per la sosta.

Questi elementi architettonici, strettamente utilitaristici, presentano al tempo stesso invenzioni decorative in cui funzione e decoro sono coniugati in modo efficace.

Fig. I. Mappa (CTR) dell'area della Franciacorta con la localizzazione schedate (elaborato grafico di L. Scaroni).

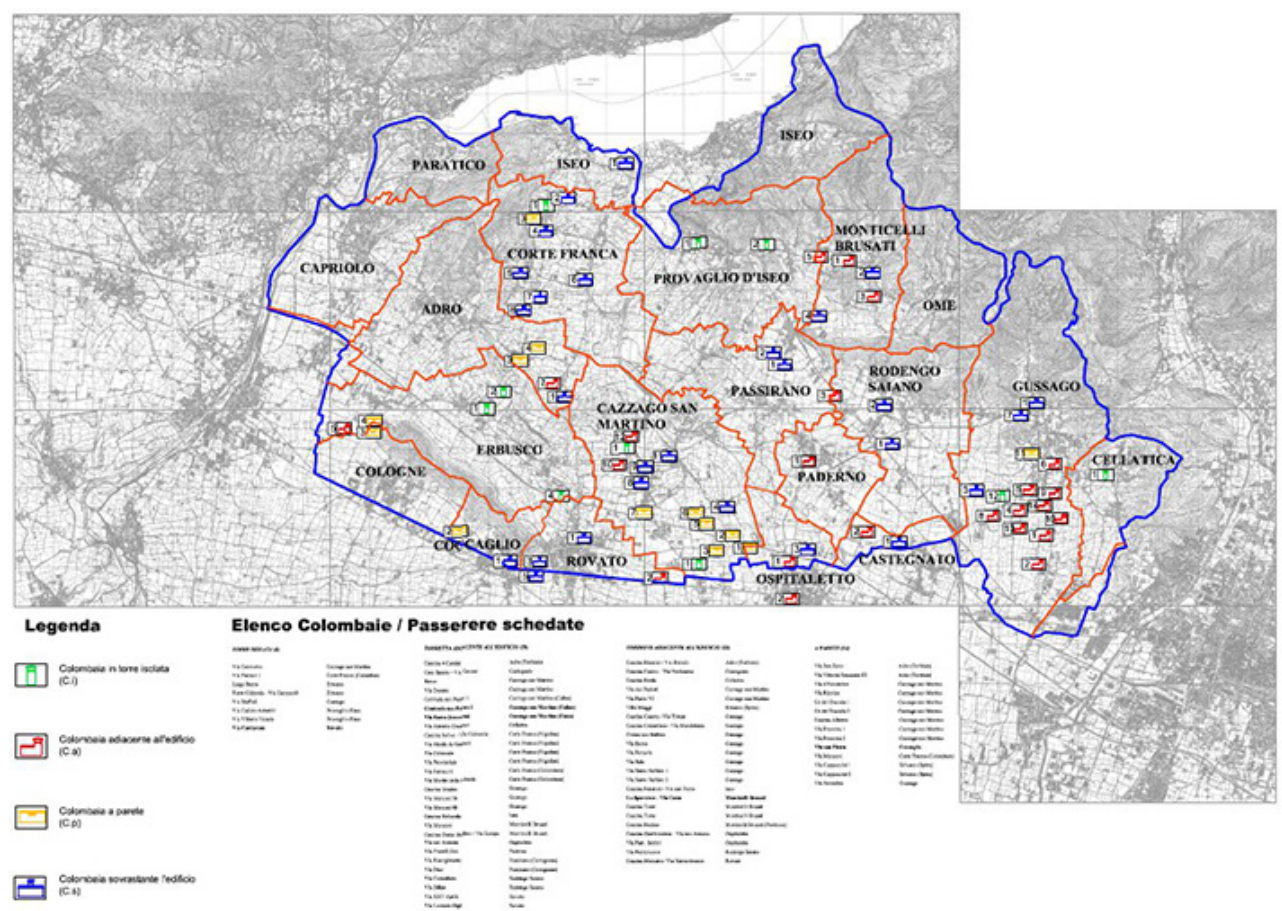




\section{Definizioni, riferimenti bibliografici principali e stato dell'arte}

II tema delle torri colombaie, tipi architettonici utilizzati in epoche e luoghi diversi per l'allevamento dei colombi, è affrontato nella produzione bibliografica in alcuni trattati di agricoltura, quali quelli di Agostino Gallo e di Pietro de' Crescenti, come si dirà più avanti; esiste anche una recente produzione edilizia, localizzata soprattutto nelle regioni con alte concentrazioni di questa tipologia, ad esempio la Campania, le Marche, il Salento. Anche nell'area bresciana si è registrato in questi ultimi anni un nuovo interesse per l'edilizia rurale che ha prodotto due volumi sui Paesaggi Agrari e le Architetture Rurali [Paoletti, Fappani 20 I5]; si tratta della realizzazione più recente sul tema, e propone un censimento ma anche alcune riflessioni su tipi e linguaggi architettonici presenti. In particolare, di colombaie, lette come una conferma dell'immagine difensiva turrita medievale reinterpretata per nuovi scopi, si parla anche nei paragrafi Casini di campagna che tratta i casi isolati nel paesaggio rurale, e Forme singolari e curiosità [Paoletti, Fappani 20I5, pp. 77, 78; 83-88], nel quale si sottolineano gli elementi peculiari di landmark.

E indubbio che la produzione bibliografica recente sia stata favorita dall'interesse per le testimonianze legate alla cultura materiale e alle attività produttive, derivante dagli orientamenti legislativi attualmente in vigore.

Con la Convenzione Europea del Paesaggio, firmata a Firenze nel 2000 e con l'avvento conseguente del Codice dei Beni Culturali e del Paesaggio del 2004, il tema dei paesaggi della vita quotidiana e l'interesse verso gli edifici del mondo rurale e le sue tradizioni hanno ricevuto il giusto interesse scientifico, diventando quindi oggetto di studi, proposte di percorsi culturali, tesi di laurea.

Si segnala inoltre l'interessante testo di Robotti che propone una lettura delle colombaie come "elementi nodali delle più antiche reti di comunicazione a distanza" [Robotti 2009] ragionando sui caratteri tipologici (distingue infatti le strutture fisse da quelle mobili o smontabili) e sulle loro funzioni, che potevano essere legate allo sviluppo o alla difesa del territorio piuttosto che alla gastronomia o alla concimazione.

Se questo esempio prende come riferimento la complessità dell'ancora esistente rete colombofila, che soddisfa il bisogno dell'uomo di comunicare e offre lo spunto per salvaguardare la memoria storica dei più antichi sistemi di organizzazione della difesa dei territori, il testo di Gabriele Rossi [Rossi 20 I2] sulle colombaie del Salento è da considerare per la sua disamina sulle caratteristiche dei singoli complessi architettonici, proponendo una organizzazione tipologica che può essere condivisibile se riferita all'area della pianura.

La ricerca è stata inizialmente affiancata da attività di tesi sul paesaggio della Franciacorta [2] e su una porzione di paesaggio della bassa pianura [3].

Queste prime attività hanno favorito il censimento dei numerosissimi esempi presenti nelle aree analizzate (fig. I). È stato così possibile predisporre delle schedature, i cui contenuti iconografici e alfanumerici forniscono un prezioso insieme di dati confrontabili e sistematizzabili. L'analisi di architetture di questo genere evidenzia alcune parole chiave sulla scorta delle quali condurre alcuni percorsi di analisi, cui si accenna brevemente.

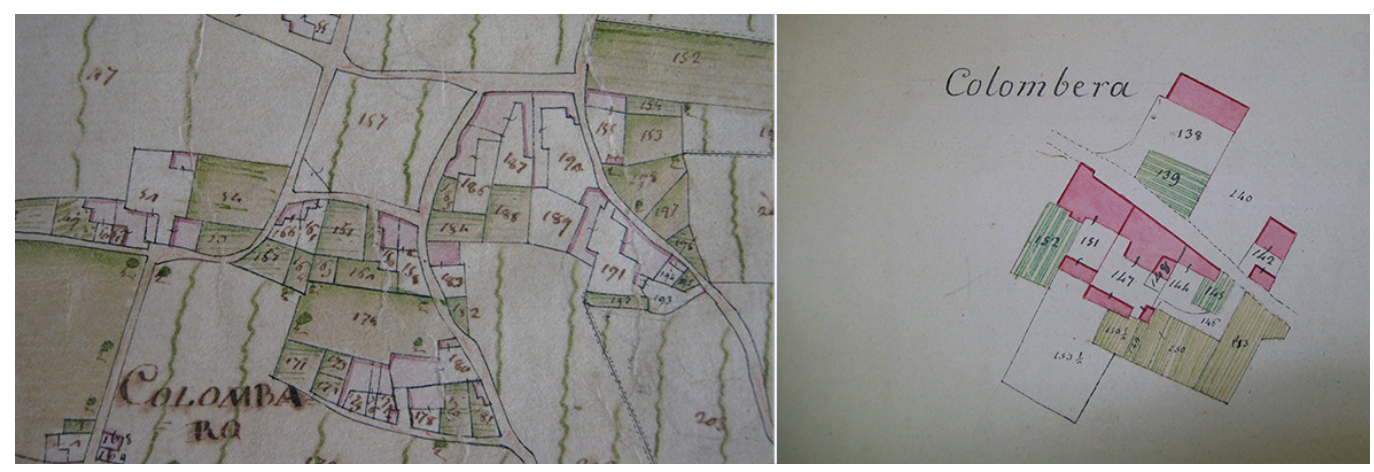




\section{I toponimi}

II toponimo Colombera o Colombaro è molto diffuso nei Catasti Storici. Ciò non prova solo la numerosità di queste architetture, ma conferma che esse siano assunte come elemento di riferimento dei luoghi. Generalmente il toponimo indica una località, un gruppo di case sparse, una frazione (fig. 2).

Gli skyline

La torre colombaia è un elemento architettonico distintivo del paesaggio di pianura. Come elemento emergente rispetto al profilo delle coperture è un landmark, punto di riferimento per gli abitanti. I profili architettonici evocano quelli delle torri difensive, ma sono resi meno minacciosi grazie ai diversi pattern geometrici derivanti dalla funzione di ricovero dei volatili (fig. 3).

Materiali in relazione agli interventi di restauro

I materiali da costruzione sono strettamente connessi alle collocazioni territoriali di questi manufatti: laterizio usato anche in modo decorativo nella Pianura (fig. 4), ciottoli di fiume in prossimità dei corsi d'acqua, pietrame e inserti di pietra di Botticino o Medolo a nord del capoluogo. Alcuni degli interventi recenti di restauro hanno evidenziato una mancanza di rispetto delle caratteristiche morfologiche e della rappresentatività che le torri colombaie hanno nel paesaggio: i fori vengono tamponati, tanto che rimane solo una labile traccia della peculiare scansione ritmica.

Le tipologie

Lo studio dei dati raccolti ha permesso di individuare le quattro tipologie ampiamente ricorrenti nei paesaggi esaminati: colombaia adiacente, sovrastante, isolata, a parete (passerera) (fig. 5). Su questo torneremo più avanti.

Fig. 3. Le torri colombaie sono riconoscibili negli skyline del paesaggio d pianura.

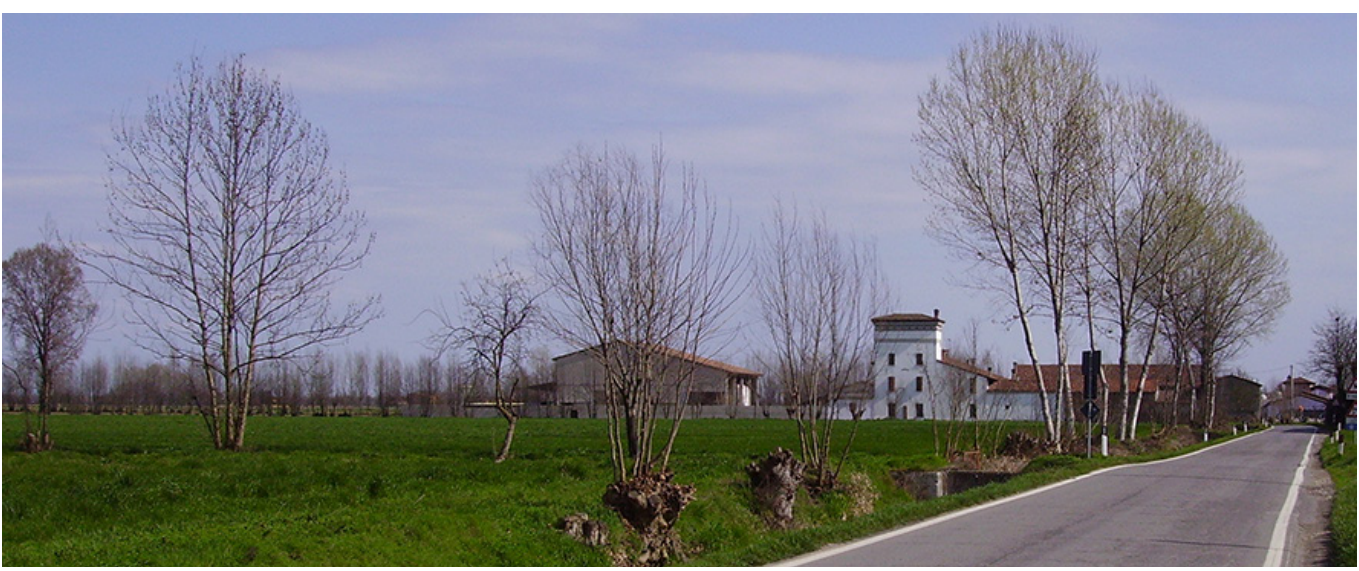

\section{Metodologie adottate nella ricerca}

Dopo un'indagine compiuta sulla trattatistica d'agricoltura per individuare gli elementi connotativi storici delle torri colombaie, si è passati all'identificazione di questi edifici sul campo, anche grazie all'utilizzo delle mappe storiche, evidenziando l'aspetto spaziale-distributivo del sistema rurale e gli aspetti tipologici delle torri.

Le informazioni selezionate hanno poi portato alla stesura di una schedatura conoscitiva su due livelli gerarchici, il primo generale, esteso alla numerosità rilevata, il secondo di dettaglio, concentrato, tramite il rilievo architettonico, sulle tipologie individuate.

Le Colombaie nella pianura lombarda orientale

"Le carni de piccioni son molto buone a mangiare, et dilettevoli, et si comprano molto volentieri. Inoltre la lor malitia è perfetta a tutte le piante, et a semi, et si può sparger in tutti i tempi dell'anno, ogni volta che si semina qualche cosa, o col seme stesso, o anche da poi. E una corba di letame di colombo val per un carro di letame di qualunque altro animale si sia" [Crescenzi 1605, libro IX, cap. XC]. 


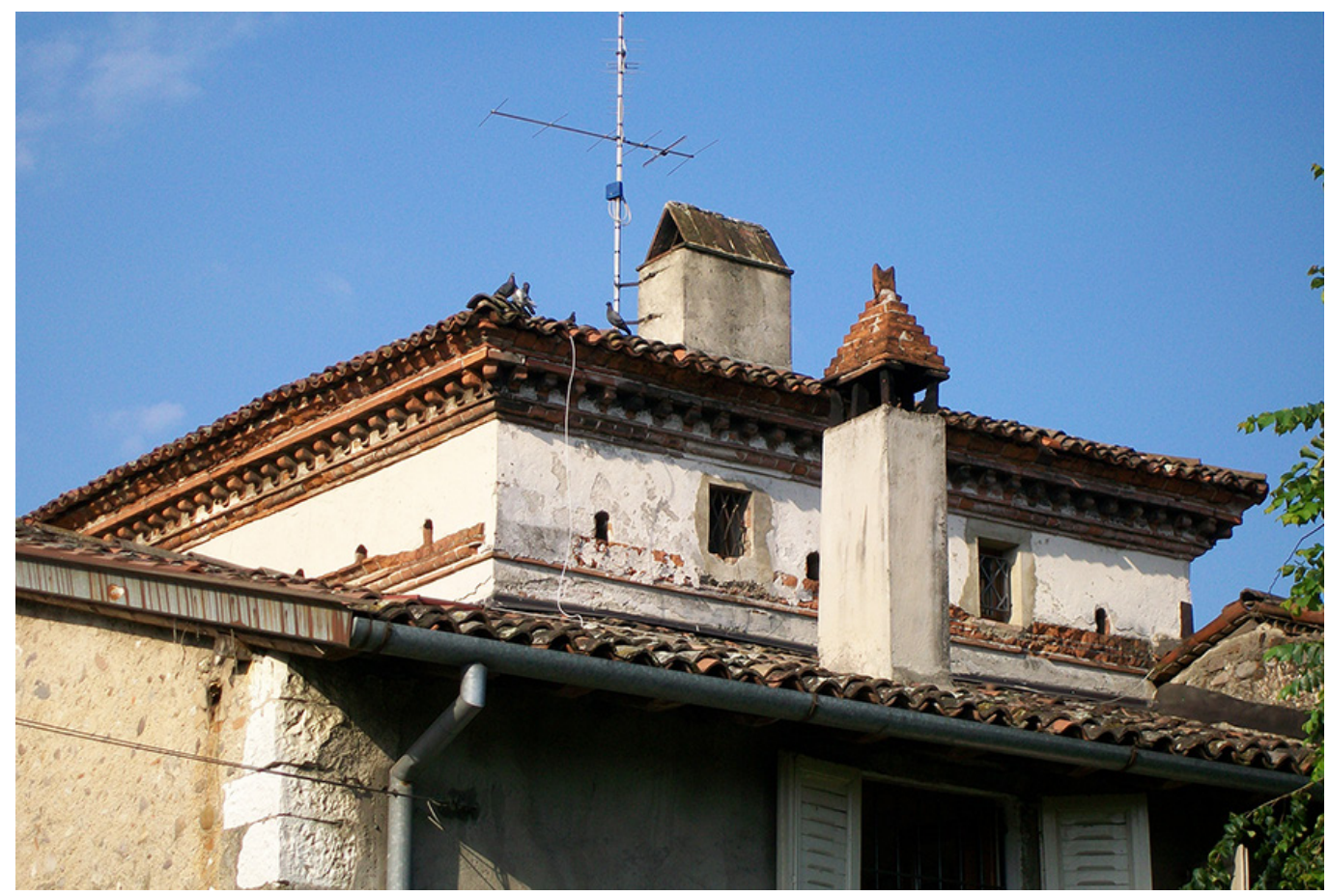

Con queste parole Pietro de' Crescenzi, scrittore e agronomo bolognese vissuto nel XIII secolo, palesa quali siano le motivazioni che indussero gli uomini all'allevamento dei colombi. Fu infatti la prelibatezza delle carni e la facilità di reperimento dell'animale, oltreché la semplicità di allevamento, che indussero gli uomini a creare dei veri e propri sistemi di allevamento dei colombi.

Inoltre, si scoprì che la deiezione di questi uccelli, la colombina, costituiva un concime più ricco e nutriente di quello derivante dalle deiezioni dei bovini. II De' Crescenzi aggiunge però anche una terza motivazione cioè la possibilità di utilizzare questi animali come messaggeri. Afferma infatti che "Oltra a ciò vi è un'altra utilità, come si dice per ogni uno, che si possono mandare in luoghi lontani in cambio di messi, con le lettere legate sotto l'ali, se si togliono da luoghi ove si debbon mandare" [Crescenzi I605, libro IX, cap. XC].

Se risulta complesso attribuire una datazione precisa alla nascita di questa pratica, sicuramente possiamo affermare che vi furono allevamenti importanti già in epoca romana come suggeriscono i trattati De re rustica di Marco T. Varrone e Lucio G.M. Columella.

Nel tardo Medioevo Pietro de' Crescenzi nel libro IX del trattato sull'Agricoltura riprese e integrò le informazioni degli scrittori latini sull'allevamento dei volatili, dalla costruzione di appositi luoghi atti ad ospitarli, le colombaie, fino alle tecniche di allevamento vere e proprie. Questo scritto, quasi dimenticato dopo la morte dell'autore, venne stampato per la prima volta in Venezia alla fine degli anni '20 del XVI secolo, seguito poi da numerose ristampe, a causa del rinnovato interesse per l'agricoltura che si sviluppò nell'ambito della Repubblica di Venezia: la creazione di grandi proprietà terriere ad opera delle nobiltà per sopperire alla diminuzione degli introiti derivanti dal commercio marittimo portò, a partire dal XV secolo, al desiderio di miglioramento delle tecniche di coltivazione e di allevamento. Ma se lo scritto dell'agronomo bolognese risultò certamente ancora valido per alcuni aspetti, non poteva però rispondere alle nuove domande scaturite dalle innovazioni che videro la luce proprio negli anni del rinascimento: nuove tecniche di coltivazione e di bonifica dei terreni (rotazione delle colture, pratica del maggese, coltura del mais, filari di gelsi), nuovi metodi di regolamentazione e sfruttamento delle acque (fontanili, costruzione di una fitta rete di rogge e canali, utilizzo intensivo dei mulini ad acqua), diffusione capillare di cascine, ville e borghi rurali. Agostino Gallo, nobiluomo bresciano, pubblicò a Venezia nel I564 Le Dieci giornate dell'agricoltura, testo ripartito in dieci capitoli in cui due gentiluomini, riunitisi in una 
villa campestre sul monte di Capriano del Colle, discutono di vari argomenti d'agricoltura. L'opera ebbe immediato successo e l'autore, dopo un'accurata revisione, la ripubblicò nel I572, ben più corposa, con il titolo Le Venti giornate dell'Agricoltura (fig. 6).

L'autore ci informa che "Ancora sommamente io lodo l'haver'una buona colombara, et più secondo la possibilità di ciascuno; percioche è cosa di utilità, et commodità per più mesi. Ma, volendole buone, vogliono esser separate da gli strepiti, dalle genti, da gli arbori, et dalle vie correnti; altramente sono molestati i colombi, et insidiati da gli uccelli di rapina. Et pero (essendo possibile) stanno bene ne gli spatiosi siti, et coltivati, et vicine alle acque correnti, accioche i colombi non vadino lontani à beccare, et bere in luoghi sospetti d'esser'amazzati, ò presi" [Gallo 1775, p. 264]. Bisogna però tenere lontani gli animali che potrebbero insidiare i volatili, in particolare "intonicando, et imbiancando cosi di dentro, come di fuori; et metten-
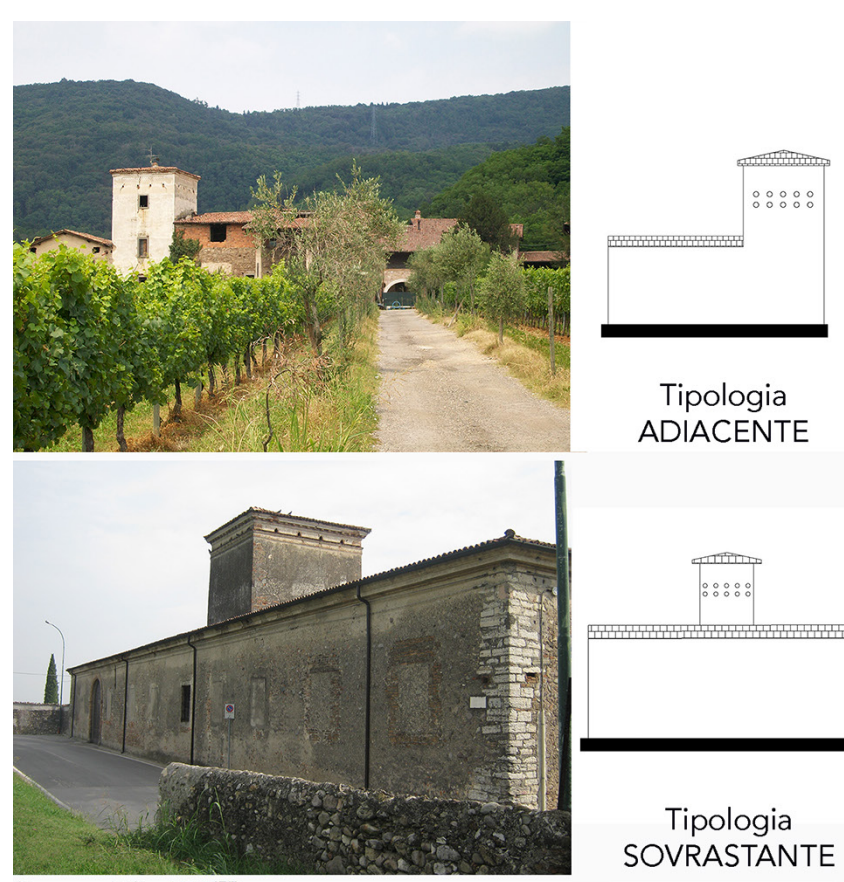

Tipologia ADIACENTE

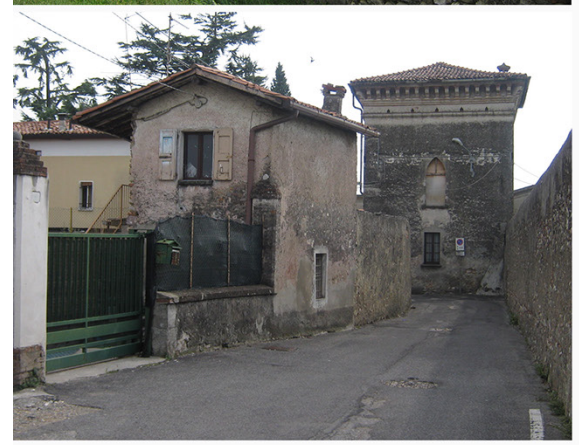

Tipologia SOVRASTANTE
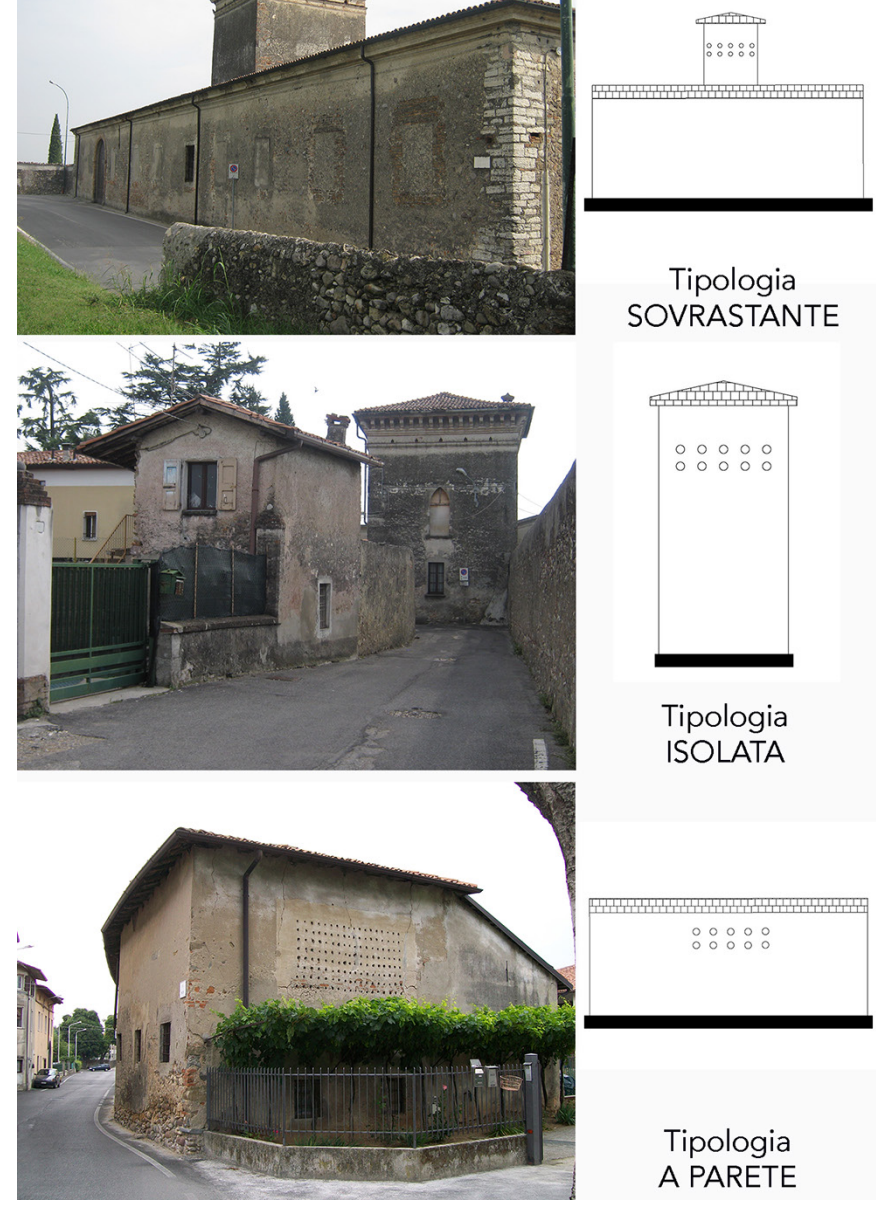

ISOLATA

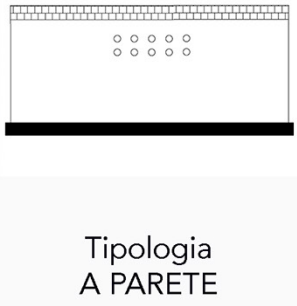


Fig. 6. Frontespizio de Le Venti Giornate dell'agricoltura di Agostino Gallo.
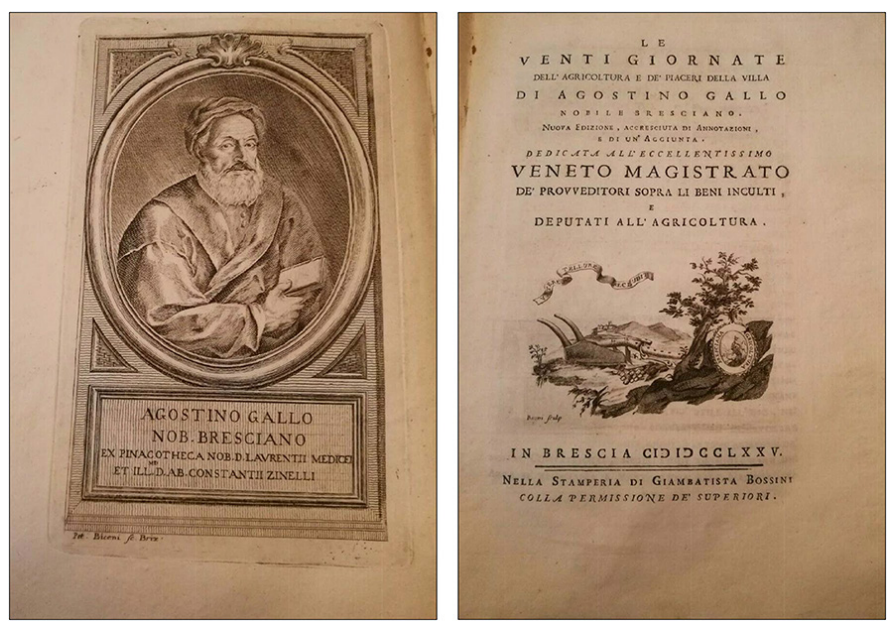

do anco sopra i cantoni le sue lamere; percioche oltra che i colombi si compiacciono della bianchezza, non sono ne anche cosi insidiati, et mangiati dalle serpi, dalle lucerte, ò da i gatti, e sorci; come spesse volte occorre nell'altre colombare" [Gallo 1775, p. 265].

Da un primo studio condotto sull'individuazione di torri colombaie nel territorio della pianura lombarda orientale si è visto che a questo modello edilizio si associa spesso la presenza di torri passerere, cioè edifici atti all'allevamento dei passeri ad uso alimentare. La prima distinzione da fare è riferibile al diametro dei fori, da cui deriva appunto la classificazione: colombaie (con fori di diametro tra 10 e $20 \mathrm{~cm}$ ) e passerere (con fori di diametro tra 5 e $8 \mathrm{~cm}$ ). L'analisi è stata compiuta su entrambe le tipologie, partendo dall'identificazione della loro presenza sul territorio e dal riconoscimento dei caratteri peculiari di ciascuna. Nel Nuovo corso completo d'agricoltura pubblicato nel I8I8 si utilizzò una definizione, valida ancor oggi, legata alla struttura edilizia: la colombaia/passerera 'a piede fermo', cioè aventi fondamenta proprie, consiste in un vero e proprio edificio con una stanza al piano terra utilizzata come magazzino per attrezzi/legumi e un piano superiore per i colombi, la colombaia/passerera 'volante', di dimensioni minori e provvista del solo spazio per i volatili, è invece edificata sopra uno stabile e per questo ben visibile dall'esterno. La catalogazione ha poi portato all'individuazione di diverse tipologie, quattro nel dettaglio, che, dopo esser state approfondite in una campagna di rilievo architettonico, sono diventate oggetto di una schedatura. Questa comprende un inquadramento territoriale, immagini, piante, sezioni e prospetti degli edifici nonché un codice ordinato di identificazione. Le varietà riscontrate sono state classificate a seconda della collocazione rispetto al complesso rurale entro cui sorgono: colomabaia/passerera 'a parete' (i fori sono distribuiti in modo geometrico, quasi sempre rettangolare, su una parete di una cascina), 'sovrastante' (piccola struttura a forma di torretta che sovrasta solitamente la cascina, fig. 7 e fig. I0), 'adiacente' (vera e propria struttura, spesso derivante da torri preesistenti, collocata come parte terminale di un edificio, fig. 09), 'isolata' (edificio a sé stante non avente comunicazione diretta con altri fabbricati, fig. 8).

\section{Obiettivi perseguiti e raggiunti}

Questa prima parte del lavoro di ricerca condotto su un'area delimitata ha permesso la raccolta di una considerevole mole di dati che ha avuto una prima elaborazione espletata nella schedatura proposta. L'indagine verrà estesa anche ad aree limitrofe per implementare la casistica e individuarne eventuali variazioni e permanenze.

Obiettivo dello studio è quello di portare a conoscenza un elemento peculiare del nostro paesaggio agrario e di consentirne, grazie alla lettura fornita dal rilievo architettonico, il recupero e la valorizzazione nell'ottica della riscoperta e salvaguardia della tradizione agricola della pianura lombarda ormai pesantemente minacciata dallo sviluppo industriale. 
Fig. 7. Scheda Torre colombala sovrastante della cascina Donati a Rovato Bs); (schemi L. Scaroni, rielaborazione grafica $M$. Pontoglio Emiliii).
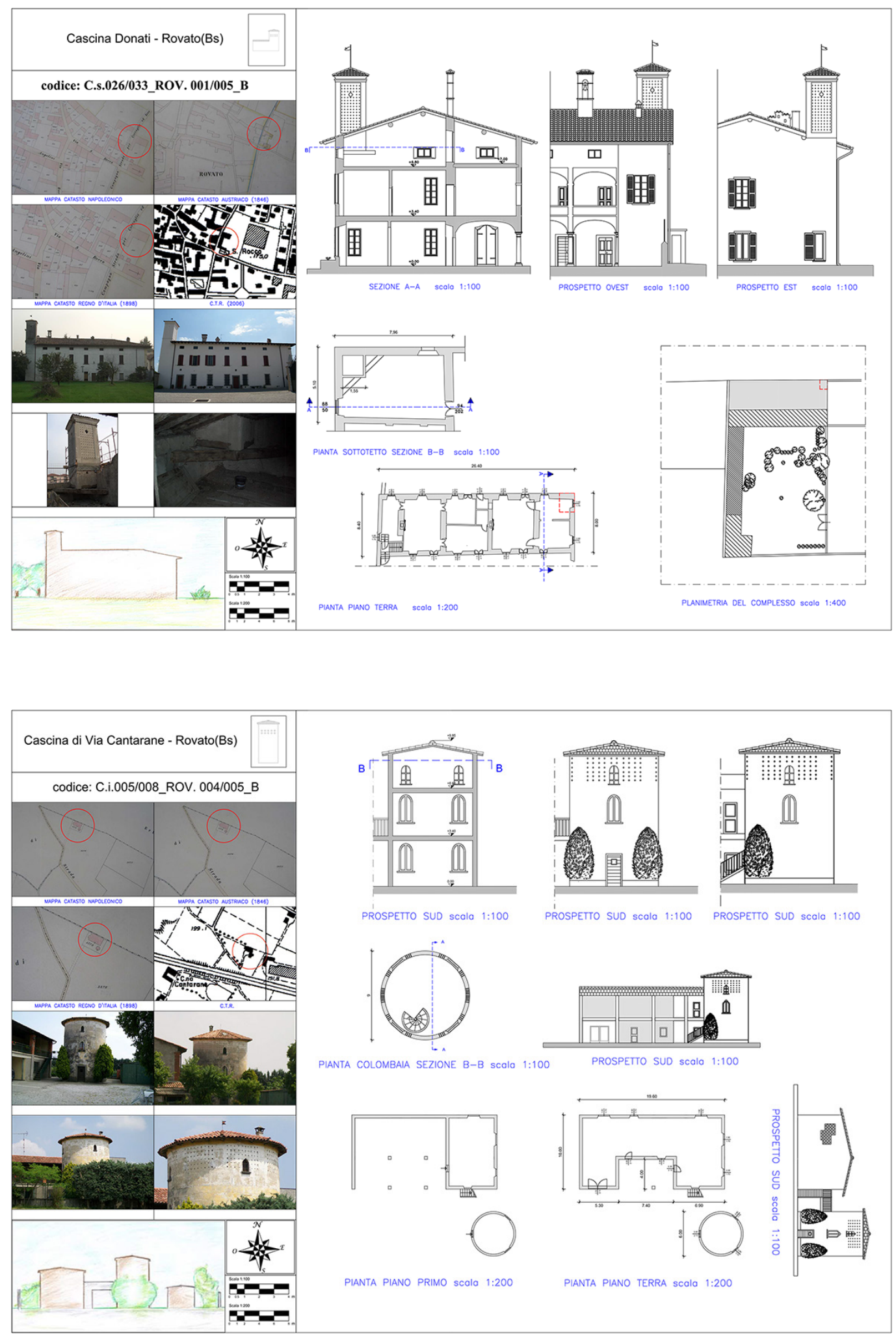
Fig. 9. Scheda Torre colombaia adiacente della cascina Sparviere a Monticelli Brusati (Bs): (schemi L. Scaroni rielaborazione grafica $M$. Pontoglio Emilii).
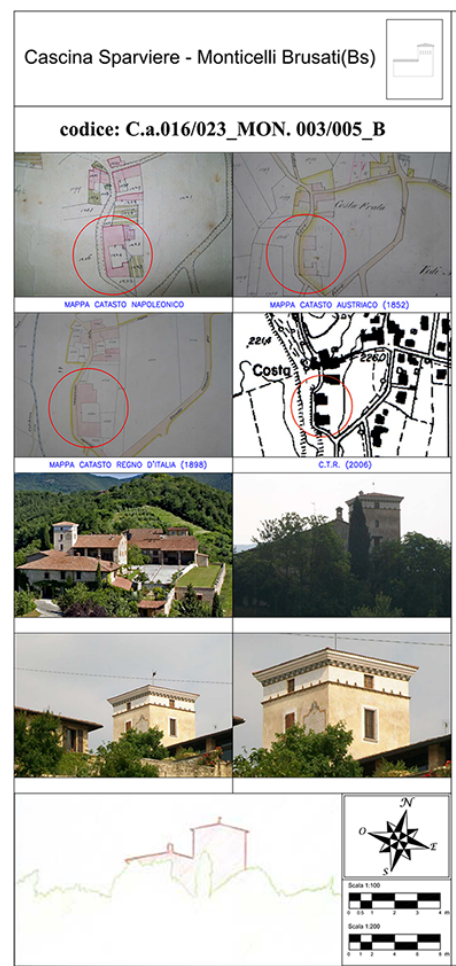
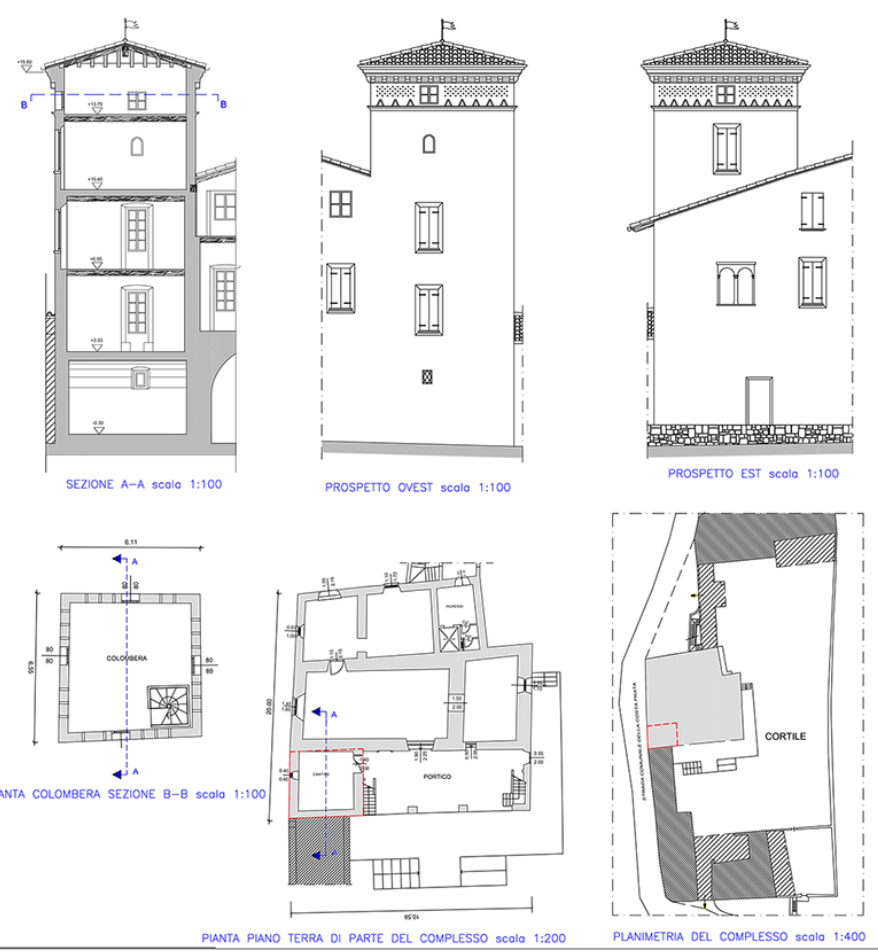

Fig 10. Scheda Torre colombaia sovrastante della cascina di C.da S. Pietro a Cazzago S. Martino (Bs). (schemi L. Scaroni, rielaborazione grafica M. Pontoglio Emilii).
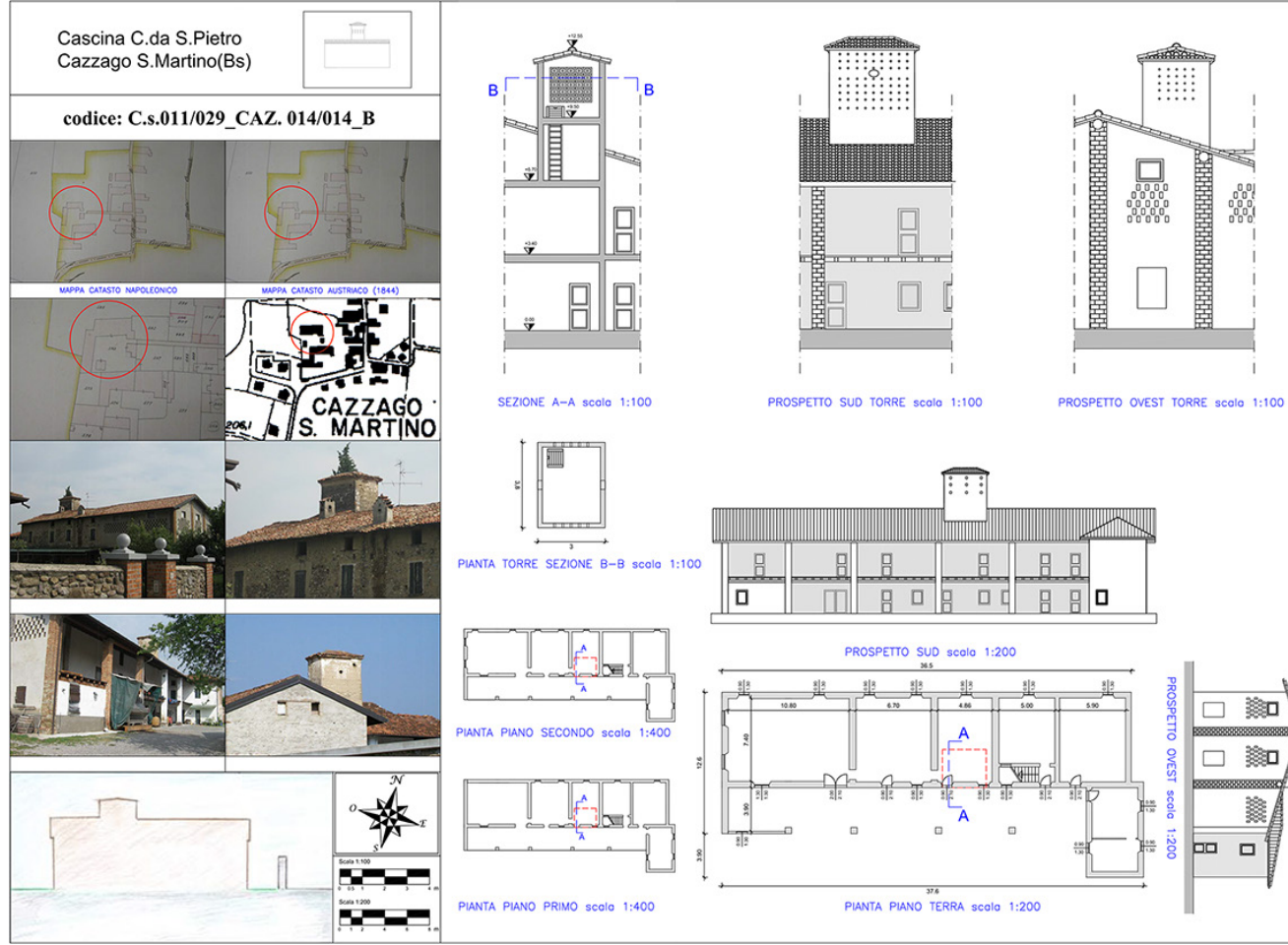

PROSPETTO SUD TORRE scalo 1:100

PROSPETIO OVEST TORPE scela 1:100
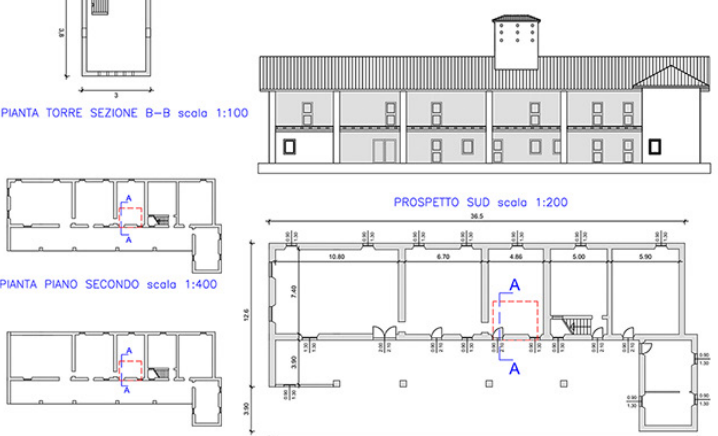

PIANTA PIANO PRIMO scolo 1:400

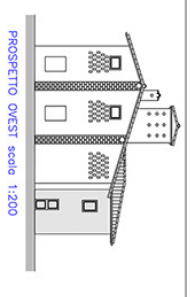




\section{Note}

[I] Pur avendo condiviso obiettivi, metodologie e risultati della ricerca, si evidenzia che Passamani è autore dei paragrafi I e 2. Pontoglio Emilii del 3 e 4.

[2] II tema delle colombaie nel paesaggio di pianura, oggetto di ricerca dal gruppo di ricerca coordinato da I. Passamani, è stato trattato nella tesi di laurea in Ingegneria Civile Triennale di Luca Scaroni Studio dei sistemi cascina-colombaie/passerere nel paesaggio della Franciacorta, relatore I. Passamani, correlatore M. Pontoglio Emilii, A.A. 20 I0/20 I I.

[3] II tema delle colombaie nel paesaggio di pianura, oggetto di ricerca dal gruppo di ricerca coordinato da I. Passamani, è stato trattato nella tesi di laurea in Ingegneria Civile Triennale di Rudy Gatti Le torri colombere/passerere nel territorio della Bassa Bresciana lungo il corso del fiume Oglio, relatore I. Passamani, correlatore M. Pontoglio Emilii, A.A. 20 I I/20I 2.

\section{Riferimenti bibliografici}

AA.W. (196I). Storia di Brescia. Brescia: Morcelliana Editrice.

AA.W. (1984). Atlante della Bassa. I. Uomini, vicende, paesi dall'Oglio al Mella. Brescia: Grafo.

AA.W. (1988). Il paesaggio della pianura bresciana. Brescia: Grafo.

Agarotti Carlo (1984). La civiltà contadina nel Bresciano. Brescia: Edizioni del Moretto.

Crescenzi (de) Pietro (1605). Trattato dell'agricoltura ... Diviso in dodici libri, ne' quali distintamente si tratta delle piante, e degli animali. Firenze: appresso Cosimo Giunti.

Gallo Agostino ( 1775). Le venti giornate dell'agricoltura e de' piaceri della villa. Ristampa anastatica (2007). Brescia: La compagnia della Stampa.

Lechi Fausto (1973). Le dimore bresciane in cinque secoli di storia. Brescia: Edizioni di Storia Bresciana.

Massetti Eugenio (a cura di). (2000). Paserére. Roccafranca: La Compagnia della Stampa/Massetti Rodella Editori.

Paoletti Dezio, Fappani Antonio (a cura di). (20 I5). Paesaggi Agrari ed Architetture Rurali nel Territorio Bresciano. Vol. I. Breno: Tipografia Camuna.

Passamani Ivana (20 I2). Alcune emergenze nel panorama di Cellatica: segni della religiosità e segni del lavoro. In AAVV. II senso del luogo. Paesaggi di Franciacorta e Sebino. Atti del Convegno di studi. Breno:Tipografia Camuna.

Rapaggi Antonio (1996). II passero sotto il tetto. In Atlante Bresciano, 49, 1996, p. 58-62.

Robotti Ciro (2009). Le torri colombaie nei paesaggi euromediterranei e del vicino Oriente: disegni, funzioni, simboli. A cura della Società di storia patria, Anno 127.

Rossi Gabriele (20I2). Le colombaie del Salento meridionale. Rilievi e documenti. Archinauti quaderni della ricerca 44. Roma: Gangemi Editore.

Sereni Emilio ( 1987). Storia del paesaggio agrario italiano. Bari: Laterza.

Thouin \& Tessier ( 18 | 8). Nuovo Corso completo d'Agricoltura teorica e pratica. Padova: Editore Crescini.

Tinelli Delfino (a cura di). (1996). Paesi e Paesaggi della Bassa Bresciana. Roccafranca: Desca Edizioni.

Traglia Antonio (a cura di). (1974). Marco Terenzio Varone. Opere. Torino: Unione Tipografico Editrice Torinese.

\section{Autori}

Ivana Passamani, Università degli Studi di Brescia, ivana.passamani@unibs.it

Matteo Pontoglio Emilii, Università degli Studi di Brescia, matteo.pontoglio@unibs.it

Per citare questo capitolo: Passamani Ivana, Pontoglio Emilii Matteo (2020). Le torri colombaie nel paesaggio di pianura. Analisi tipologiche, rilievo architettonico per la conoscenza/The dovecote towers in the Po Valley landscape. Typological Analysis, Architectural Survey to Knowledge. In Arena A. Arena M., Brandolino R.G.. Colistra D. Ginex G. Mediati D. Nucifora S. Raffa P. (a cura di). Connettere. Un disegno per annodare e tessere Atti del $42^{\circ}$ Convegno Internazionale dei Docenti delle Discipline della Rappresentazione/Connecting. Drawing for weaving relationships. Proceedings of the 42 th International Conference of Representation Disciplines Teachers. Milano: FrancoAngeli, pp. 255 I-2570. 


\title{
The Dovecote Towers in the Po Valley Landscape. Typological Analysis, Architectural Survey to Knowledge
}

\author{
Ivana Passamani \\ Matteo Pontoglio Emilii
}

Abstract

The dovecote tower is a distinctive architectural element of the Franciacorta and of the Po Valley. Studying this architecture used to the rearing of birds allows us to identify a landmark common for many European and non-European landscapes. The dovecotes were used for food, as messangers but also as producers of fertilizer. We can therefore define the pigeon as a ring of a circular agricultural economy, and the dovecote tower as a symbol of a sustainable economic process, in which nothing was fortuitous or was wasted. The research investigates the phenomenon of dovecote towers located in the rural landscape, to identify the main connotations and the formal elements. In the territory of the eastern plain it is usual to breed sparrows too, in order to use the meat to prepare the traditional spiedo. Thus the sparrows towers were built, likewise to the dovecotes structures. The bibliography on the subject offers some monographs, texts or articles and some studies. Referring to some historical agricultural treaties, we highlight the constructive characteristics suggested for these architectures. The research methodology considers several phases: historical-bibliographic research; filing; survey of significative examples; systematization in synoptic tables. Objectives: to catalog the dovecote/sparrow towers; to characterize the connotative elements; to identify the adopted historical-architectural references.

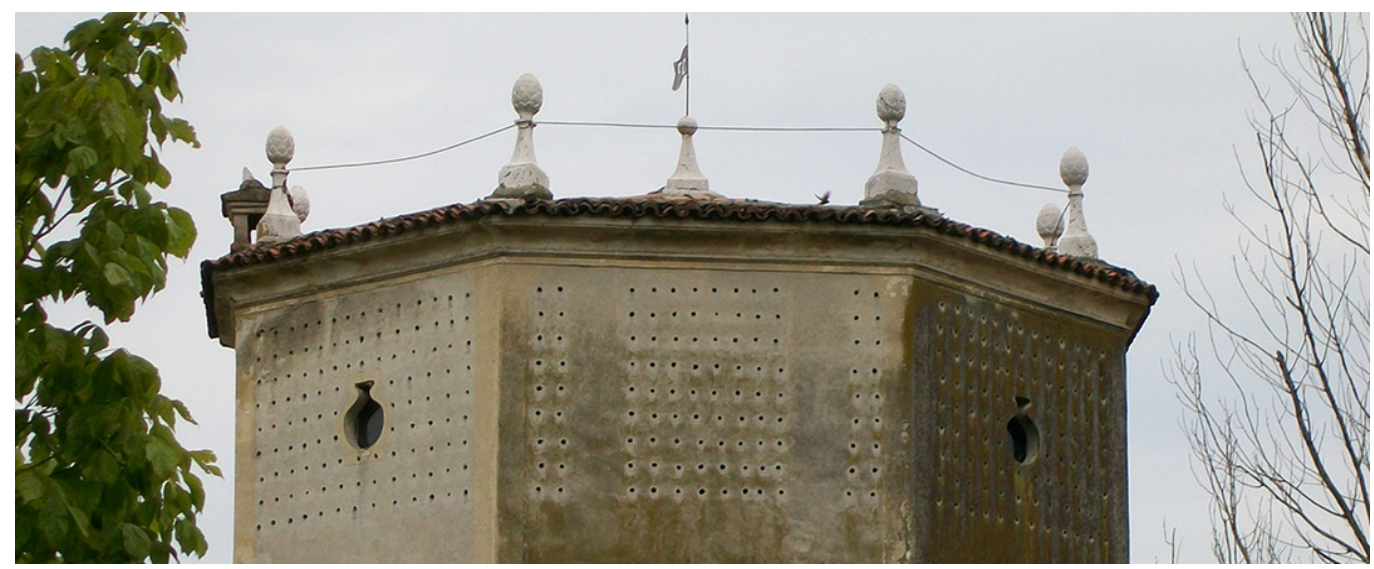




\section{The topic}

Even in its specificity the dovecote tower, in the visual experience of the landscape of the plain, is an integral and identifying part of the farmhouse, "the new corporate center of the large capitalist rental, which becomes the center of reorganization of the entire agricultural landscape of the Po Valley" [Sereni 1987, p. 338] [I].

This architectural element belongs to human history since the breeding of birds has been practiced since ancient times. In fact, it is possible to distinguish dovecote towers in the skylines and in the plains of various European and non-European landscapes, and it is significant to think that for a few other animals man has designed specialized buildings for breeding, which at the same time express peculiar decorative and formal characters.

The variety of solutions we can find on the international scene, in fact, suggests that the design was not limited to the search for the best functional solutions, but also sought decorative-perceptive effects that are always original but, at the same time, consistent with local resources.

A demonstration of the importance that the dove had in the Greek world is that in ancient Attica it was a mythological bird. Its symbolic meanings, moreover, cross peoples and religions. Pigeons were used for feeding but also as messengers; in addition, the dung produced was considered the best fertilizer for agriculture, as evidenced by Varrone [Traglia 1974, p. 828].

We can define dovecotes as machine-buildings: in fact they repeat the same distribution and organizational characteristics, functional to the life and to the breeding of the hosted animal. No detail or element is random, but it makes possible the daily life of the bird and the satisfaction of its needs.

The buildings are equipped with a single door for the breeder's entrance, the windows Carthaginian style and a particular type of very smooth plaster prevent snakes or other animals from entering; the small holes that pierce the masonry, called eyes, allow the pigeons to enter and exit while small cantilevered shelves or molded continuous frames offer a resting surface.

These architectural elements, strictly utilitarian, present at the same time decorative inventions in which function and decoration are effectively combined.

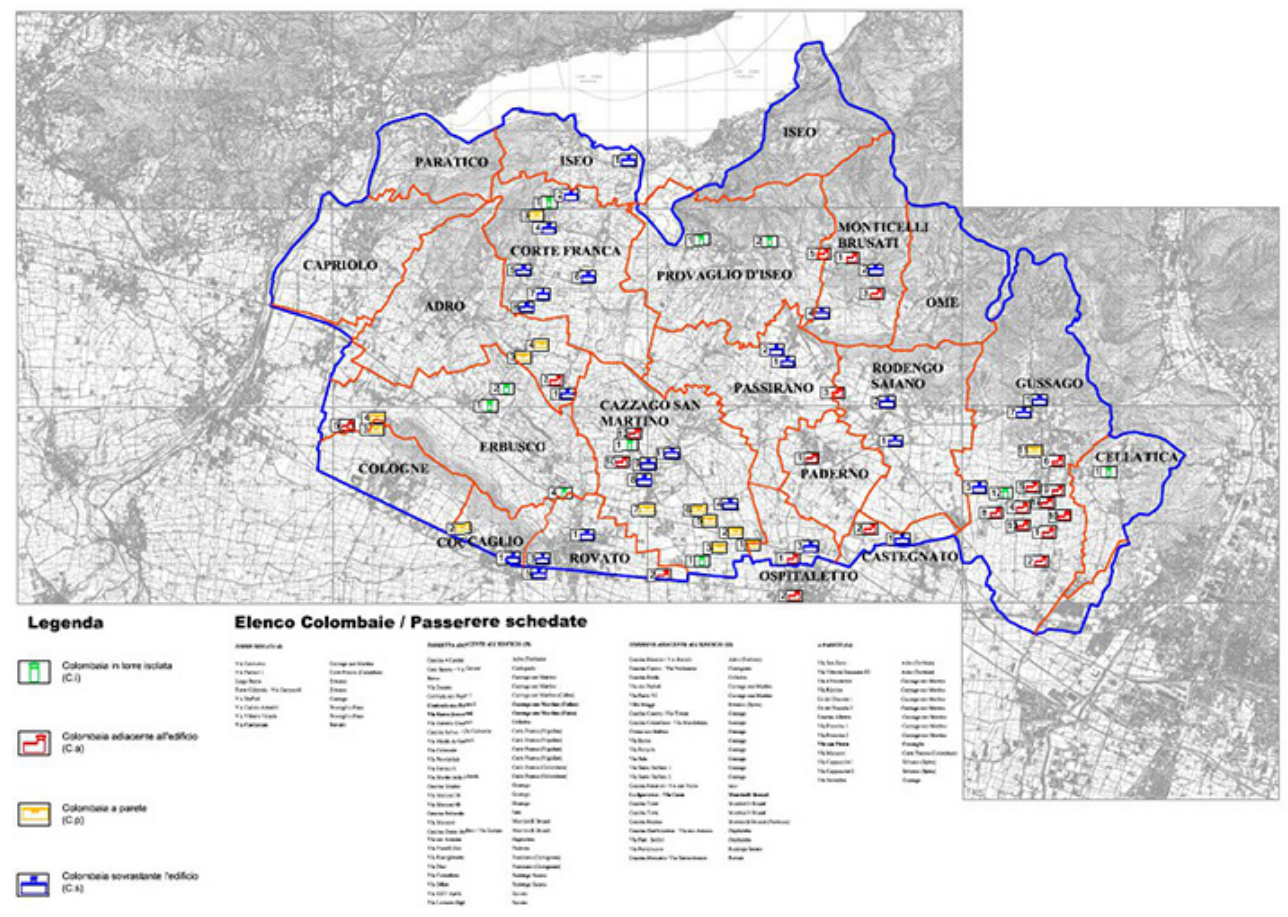




\section{Definitions, current status and main bibliographical references}

The theme of dovecote towers, architectural types used in different eras and places for the breeding of pigeons, is addressed in the bibliographic production in some agricultural treatises, such as those of Agostino Gallo and Pietro de' Crescenti, as will be said later; there is also a recent bibliographic production, mainly located in italian regions with high concentrations of this type, for example Campania, Marche, Salento.

Also in the area of Brescia, in recent years there has been a new interest in rural construction which has produced two volumes on Paesaggi Agrari e le Architetture Rurali [Paoletti, Fappani 20 I5]; this is the most recent study on the subject, and proposes a census but also some considerations on the types and on the architectural languages observed in the research.

In particular the dovecotes, read as a confirmation of the medieval turreted defensive image reinterpreted for new purposes, are also mentioned in the paragraphs Casini di Campagna which deals with isolated cases in the rural landscape, and Forme singolari e curiosità [Paoletti, Fappani 2015, pp. 77, 78; 83-88], in which the distinctive landmark elements are highlighted. There is no doubt that the recent bibliographic production was favored by the interest in the testimonies related to material culture and to production activities, deriving from the legislative guidelines currently in force.

Thanks to the European Landscape Convention, signed in Florence in 2000 and thanks to the consequent advent of the Codice dei Beni Culturali e del Paesaggio in 2004, the theme of the landscapes of everyday life and the interest in the buildings belonging to the rural world and in the traditions of this world finally received the right scientific interest, thus becoming the focus of studies, proposals for cultural itineraries, degree theses.

We also report the interesting text of Robotti which proposes a reading-key of dovecotes as "elementi nodali delle più antiche reti di comunicazione a distanza", reasoning about the typological characters (in fact he distinguishes the fixed structures from the mobile or removable ones) and about their functions, which could be related to the development or defense of the territory rather than to gastronomy or to fertilization activity.

This example takes as a reference the complexity of the still existing pigeon network, which satisfies man's need to communicate and offers the starting point to safeguard the historical memory of the most ancient systems of organization for the defense of the territories; Gabriele Rossi's text on dovecotes of Salento [Rossi 20I2] is to be considered for its deal with the characteristics of the individual architectural complexes. It proposes a typological organization that can be shared if it refers to the area of the plain.

Our research was initially accompanied by some research activities concerning the landscape of Franciacorta [2] and on a portion of the landscape of the plain [3].

These first activities favored the census of the numerous examples present in the analyzed areas (fig. I). It was thus possible to prepare filings, whose iconographic and alphanumeric contents provide a valuable set of comparable and systematic data.

The analysis of such type of architectures highlights some interesting keywords: we conduct some analysis referring to these keywords, which are briefly mentioned.

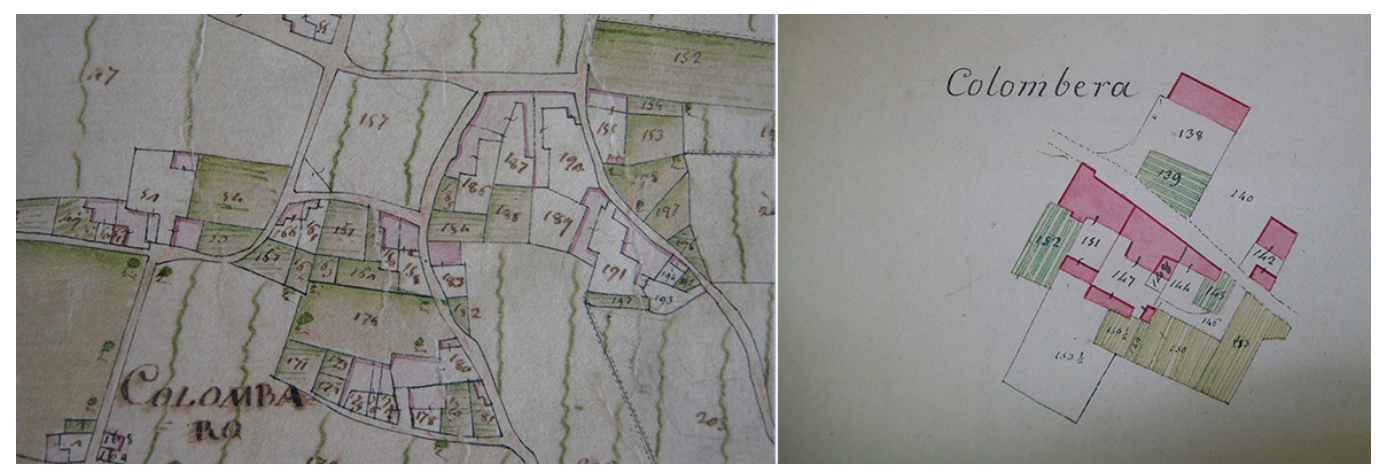




\section{Toponyms}

The toponym Colombera or Colombaro is widespread in the historical Cadastres. This not only proves the diffusion of these architectures, but confirms that they are taken as a reference element of many areas. Generally the toponym indicates a locality, a group of scattered houses, a hamlet (fig. 2).

Skylines

The dovecote tower is a distinctive architectural element of the plain landscape. As an emerging element in connetion to the profile of the roofs, it is a landmark, a reference point for the inhabitants. The architectural profiles evoke those of the defensive towers, but are less threatening thanks to the different geometric patterns deriving from the bird shelter function (fig. 3).

Materials versus restoration interventions

The building materials are closely connected to the territorial locations of these artefacts: brick also used in a decorative way in the plain (fig. 4), river pebbles near rivers, stones and stone inserts of Botticino or Medolo stone to the north of the capital.

Some recent restoration interventions have highlighted no respect for the morphological characteristics and representativeness that dovecote towers have in the landscape: the holes are buffered, so much so that only a faint trace of the peculiar rhythmic scanning remains. Typologies

The study of the collected data made it possible to identify the four widely recurring typologies in the examined landscapes: adjacent, overhanging, isolated, wall dovecote (passerera) (fig. 5). We will come back to this later.

Fig. 3. The dovecote towers are recognizable in the plain landscape skylines.

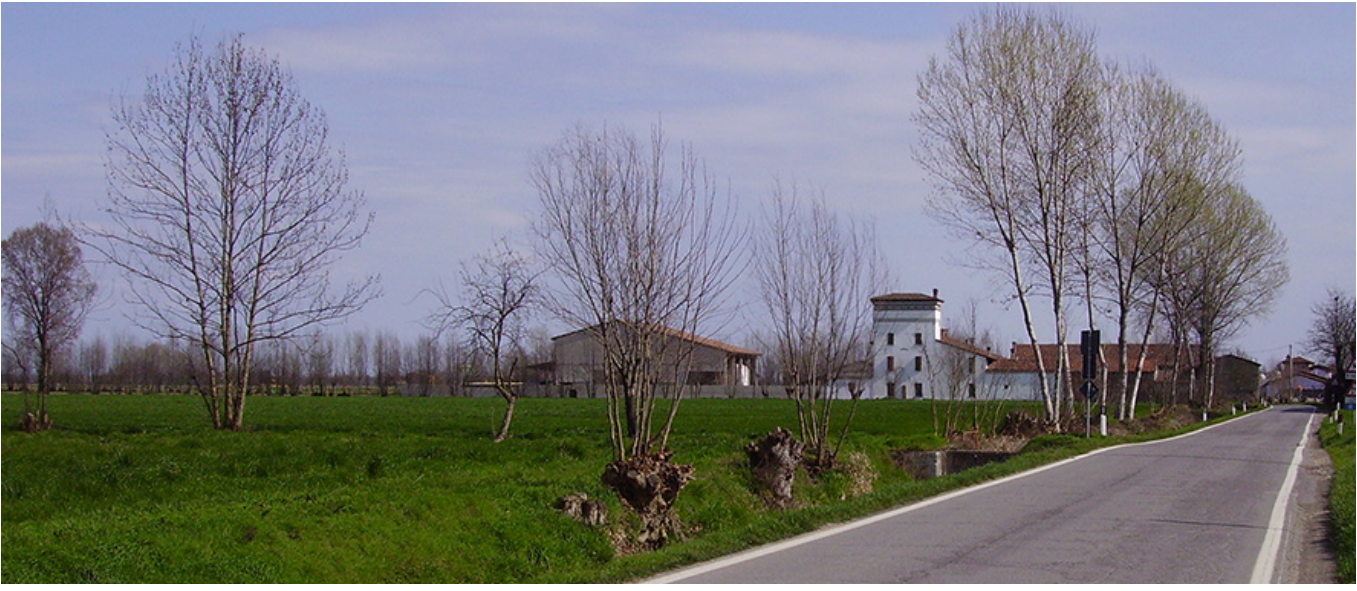

Methodologies used in research

After an analysis of the agricultural treaties to identify the historical connotative elements of the dovecote towers, we moved on to the identification of these buildings, using historical maps, highlighting the spatial-distributive aspect of the rural system and the typological aspects of the towers.

The information collected allowed the creation of a cataloging on two hierarchical levels, the first general, extended to the number detected, the second more detailed, through the architectural survey, on the types identified.

The dovecote towers in the eastern lombard plan "Le carni de piccioni son molto buone a mangiare, et dilettevoli, et si comprano molto volentieri. Inoltre la lor malitia è perfetta a tutte le piante, et a semi, et si può sparger in tutti i tempi dell'anno, ogni volta che si semina qualche cosa, o col seme stesso, o anche da poi. E una corba di letame di colombo val per un carro di letame di qualunque altro animale si sia" [Crescenzi I605, libro IX, cap. XC]. 
Fig. 4. Brick's practice in a dovecote tower located in Gussago (Bs).

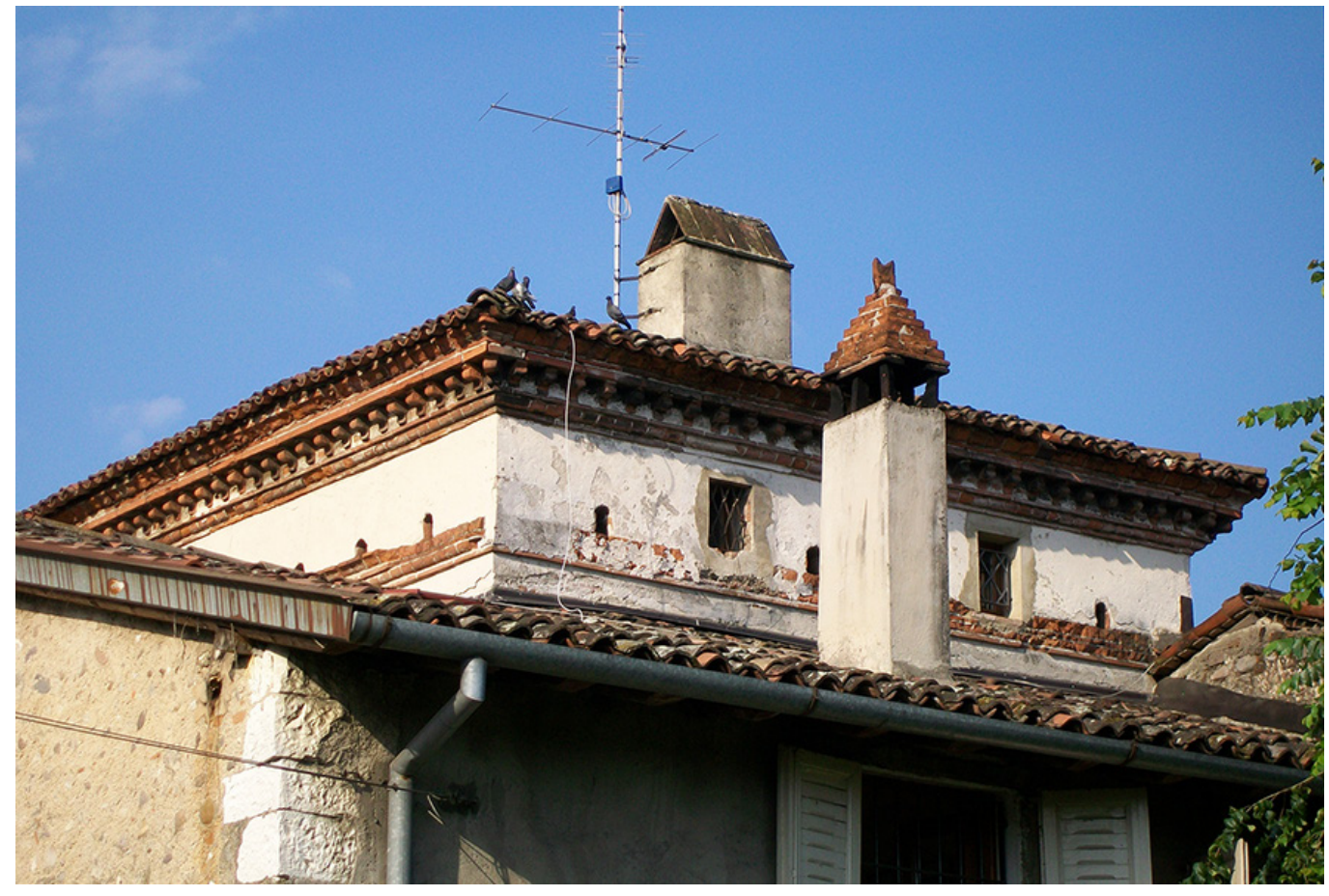

With these words Pietro de' Crescenzi, a Bolognese writer and agronomist who lived in the thirteenth century, shows what the reasons were that led men to the breeding of pigeons. The delicacy of the meat and the ease of finding the animal, as well as the simplicity of breeding, induced men to create real pigeon breeding systems.

Furthermore, it was discovered that the dejection of these birds, the columbine, constituted a richer and more nutritious fertilizer than that deriving from the manure of the cattle.

De' Crescenzi also adds a third motivation, namely the possibility of using these animals as messengers. In fact, he affirms that "oltra a ciò vi è un'altra utilità, come si dice per ogni uno, che si possono mandare in luoghi lontani in cambio di messi, con le lettere legate sotto l'ali, se si togliono da luoghi ove si debbon mandare" [Crescenzi I605, libro IX, cap. XC].

Although it is complex to attribute a precise dating to the birth of this practice, we can certainly say that there were important farms already in Roman times as we read in the De re rustica treatises by Marco T.Varrone and Lucio G.M. Columella.

In the late Middle Ages, Pietro de' Crescenzi in his treatise on Agriculture resumed and integrated the information of Latin writers on the breeding of birds, from the construction of special places suitable for hosting them, the dovecotes, up to real breeding techniques.

This book, almost forgotten after the author's death, was printed for the first time in Venice in the early 16th century, followed by numerous reprints, due to the renewed interest in agriculture promoted by the Republic of Venice: the creation of great landed properties by the nobility to compensate for the decrease in the profits of the maritime trade led, starting from the fifteenth century, to the desire to improve cultivation and breeding techniques.

There were many innovations that arose in the Renaissance years: new techniques of cultivation and land reclamation (crop rotation, fallow practice, maize cultivation, rows of mulberries), new methods of regulation and use of water (fountains, construction of a dense network of irrigation ditches and canals, intensive use of water mills), widespread diffusion of farmhouses, villas and rural villages.

Agostino Gallo, a nobleman from Brescia, published The Ten Days of Agriculture in Venice in 1564, a text divided into ten chapters in which two gentlemen, gathered in a country villa on the mountain of Capriano del Colle, talk about various agricultural topics. The book was an immediate success and the author, after a careful revision, republished it in I572, much more substantial, with the title The Twenty Days of Agriculture (fig. 6). 
The writer informs us that "Ancora sommamente io lodo l'haver'una buona colombara, et più secondo la possibilità di ciascuno; percioche è cosa di utilità, et commodità per più mesi. Ma, volendole buone, vogliono esser separate da gli strepiti, dalle genti, da gli arbori, et dalle vie correnti; altramente sono molestati i colombi, et insidiati da gli uccelli di rapina. Et pero (essendo possibile) stanno bene ne gli spatiosi siti, et coltivati, et vicine alle acque correnti, accioche i colombi non vadino lontani à beccare, et bere in luoghi sospetti d'esser'amazzati, ò presi" [Gallo I775, p. 264 ]. It is necessary to remove animals that could threaten birds, in particular "intonicando, et imbiancando cosi di dentro, come di fuori; et mettendo anco sopra i cantoni le sue lamere; percioche oltra che i colombi si compiacciono della bianchezza, non sono ne anche cosi insidiati, et mangiati dalle serpi, dalle lucerte, ò da i gatti, e sorci; come spesse volte occorre nell'altre colombare" [Gallo 1775, p. 265].

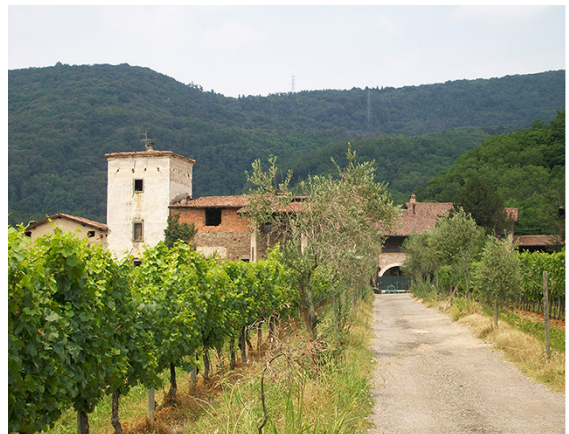

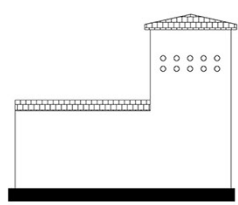

Tipologia ADIACENTE
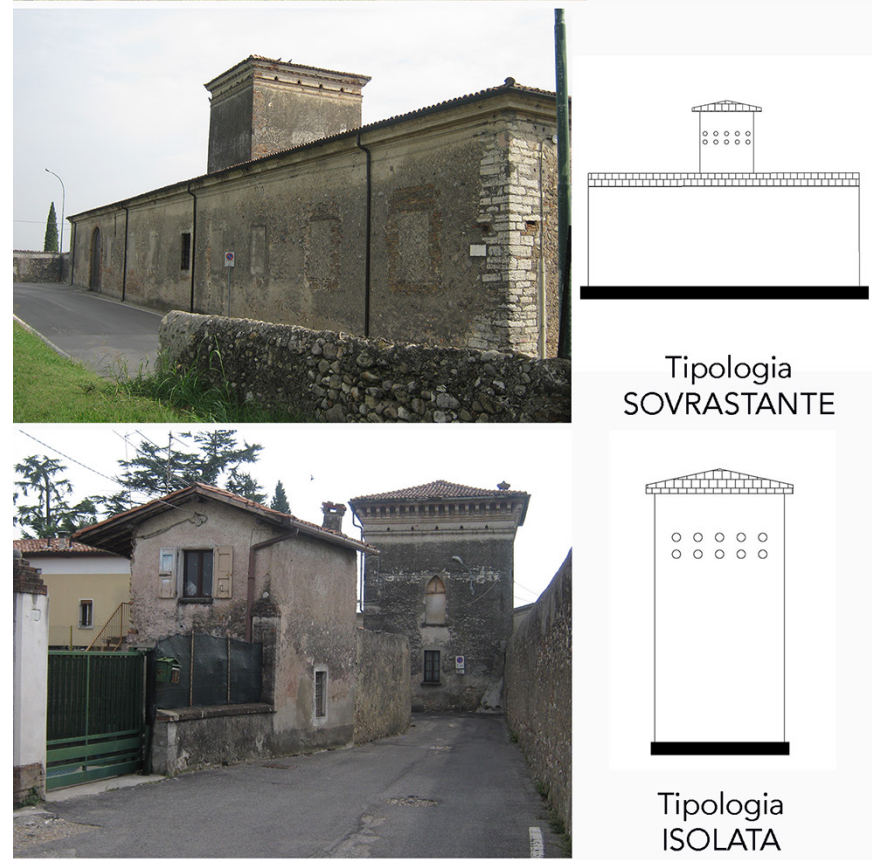

SOVRASTANTE
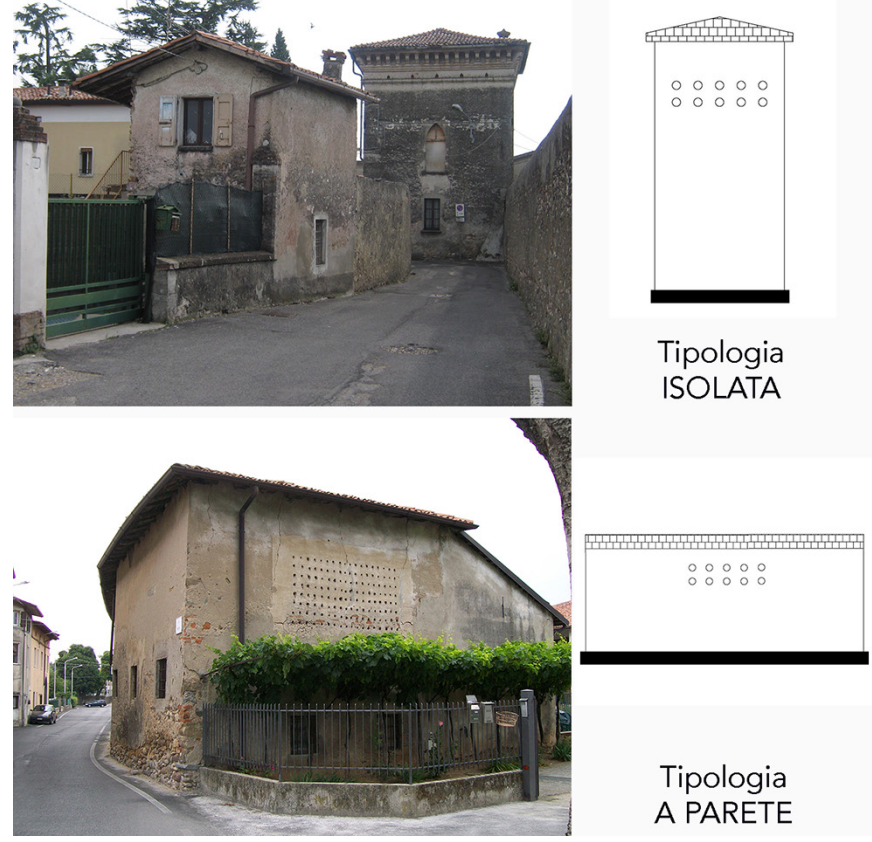

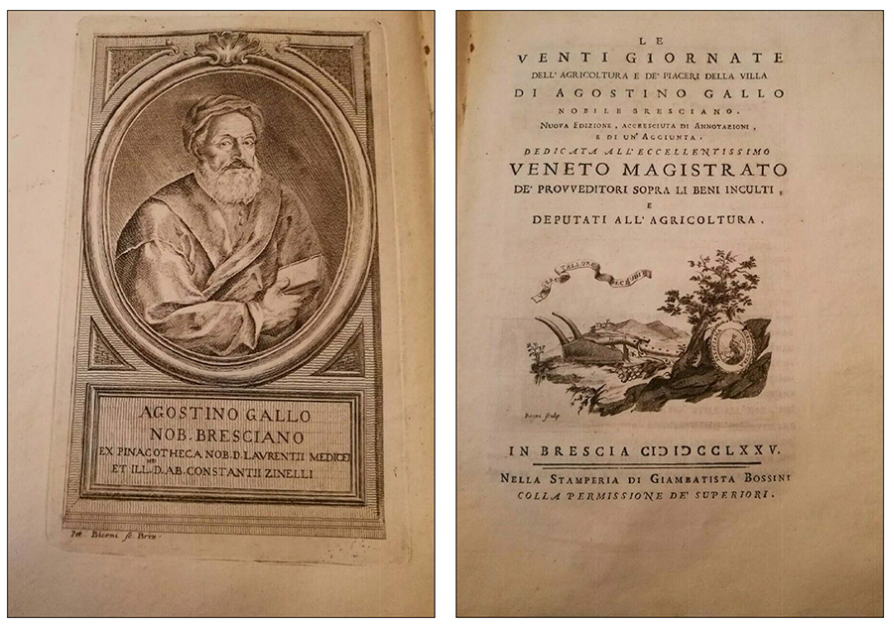

From a first study conducted on the identification of dovecote towers in the territory of the eastern Po Valley, it was seen that this building model is often associated with the presence of sparrow towers (passerere), buildings suitable for the breeding of sparrows for food use. The first important distinction refers to the diameter of the holes, from which the classification derives: dovecote towers (with holes of diameter between 10 and $20 \mathrm{~cm}$ ) and sparrow towers (with holes of diameter between 5 and $8 \mathrm{~cm}$ ).

The analysis was carried out on both types, starting from the identification of their presence on the territory and the recognition of the peculiar characteristics of each. In the "Nuovo corso completo d'agricoltura" published in $|8| 8$, a definition was used, still valid today, linked to the building structure: the a piede fermo (with the foot still) dovecote/sparrow tower consist of a real building with a room on the ground floor used as a warehouse for tools/ legumes and an upper floor for pigeons, instead the volante (flying) dovecote/sparrow tower, smaller in size and with only one room for birds, it is erected on top of a building and therefore clearly visible from the outside.

The study identified different types, four in detail, which, through the architectural survey, have become the subject of a cataloging. This includes a territorial framework, images, plans, sections and perspective drawing of the buildings as well as an ordered identification code. The typologies found were classified according to their location with respect to the rural complex within which they arise: a parete (on the wall) dovecote/sparrow tower (the holes are distributed geometrically, almost always rectangular, on a wall of a farmhouse), sovrastante (above-small turret structure that usually overlooks the farmhouse), (fig. 7, fig. I0), adiacente (adjacent-real structure, often deriving from pre-existing towers, located as the end part of a building), (fig. 9), isolata (isolated-stand-alone building without connecting buildings (fig. 8).

\section{Expected and achieved objectives}

This first part of the research, conducted on a delimited area, allowed the collection of a considerable amount of data which had a first processing flowed into the proposed cataloging. The investigation will also be extended to neighboring areas to implement the case studies and identify any changes and stays.

The purpose of the study is twofold: to know a peculiar element of our agricultural landscape and to allow, thanks to the architectural survey, the restoration and the appreciation to safeguard the agricultural tradition of the Po Valley now heavily threatened by industrial development. 
Fig. 7. Above dovecote tower in Donati farmhou se located in Rovato (Bs), (fracated in Rovato (Bs), (framework by L. Scaron. Paphic elaboration by $M$. Pontoglio Emilii).

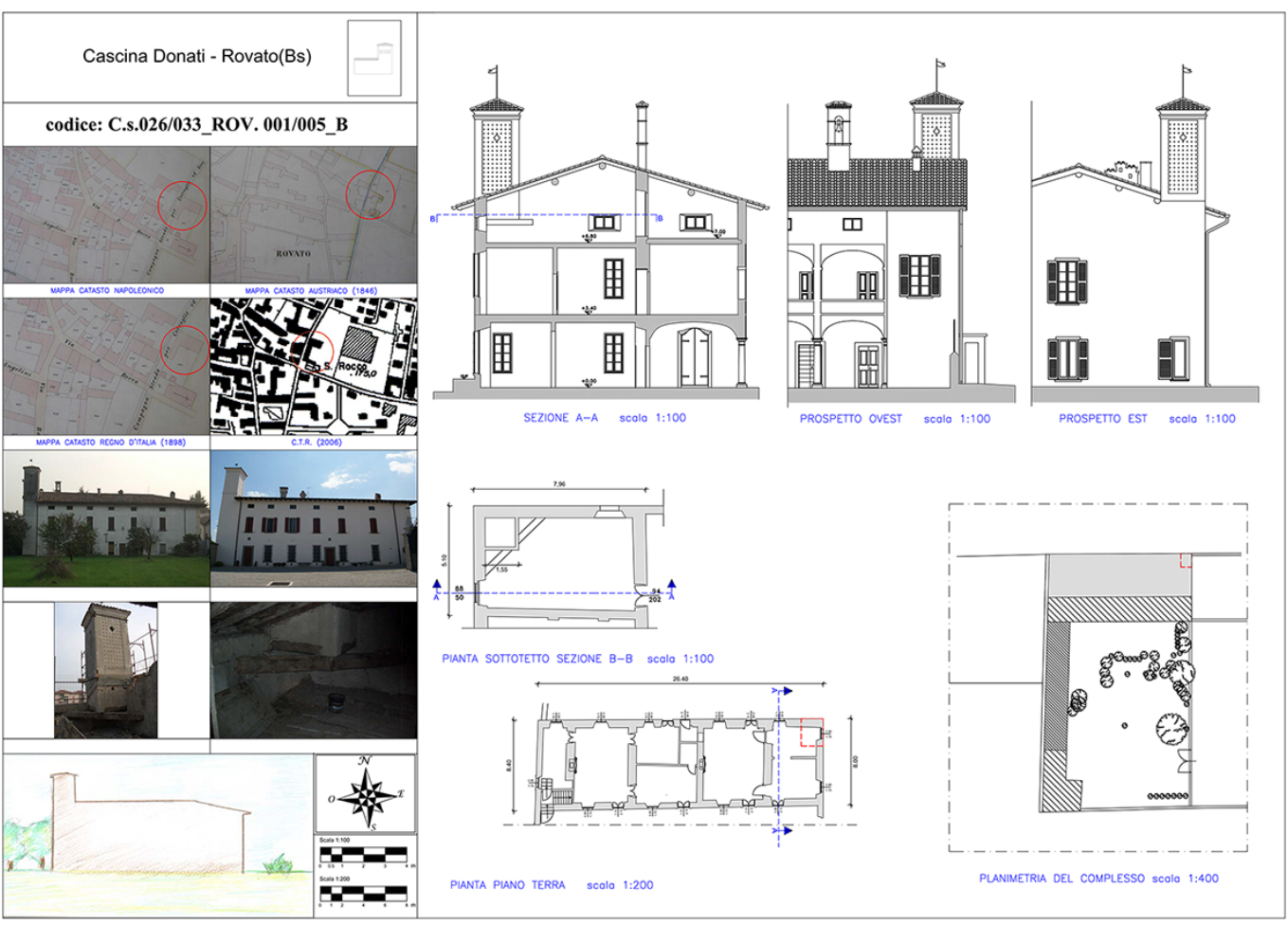

Fig. 8. Isolated dovecote tower in Cantarane farmhouse located in Rovato (Bs). (framework by L. Scaroni, graphic elaboration by M. Pontoglio Emilii)

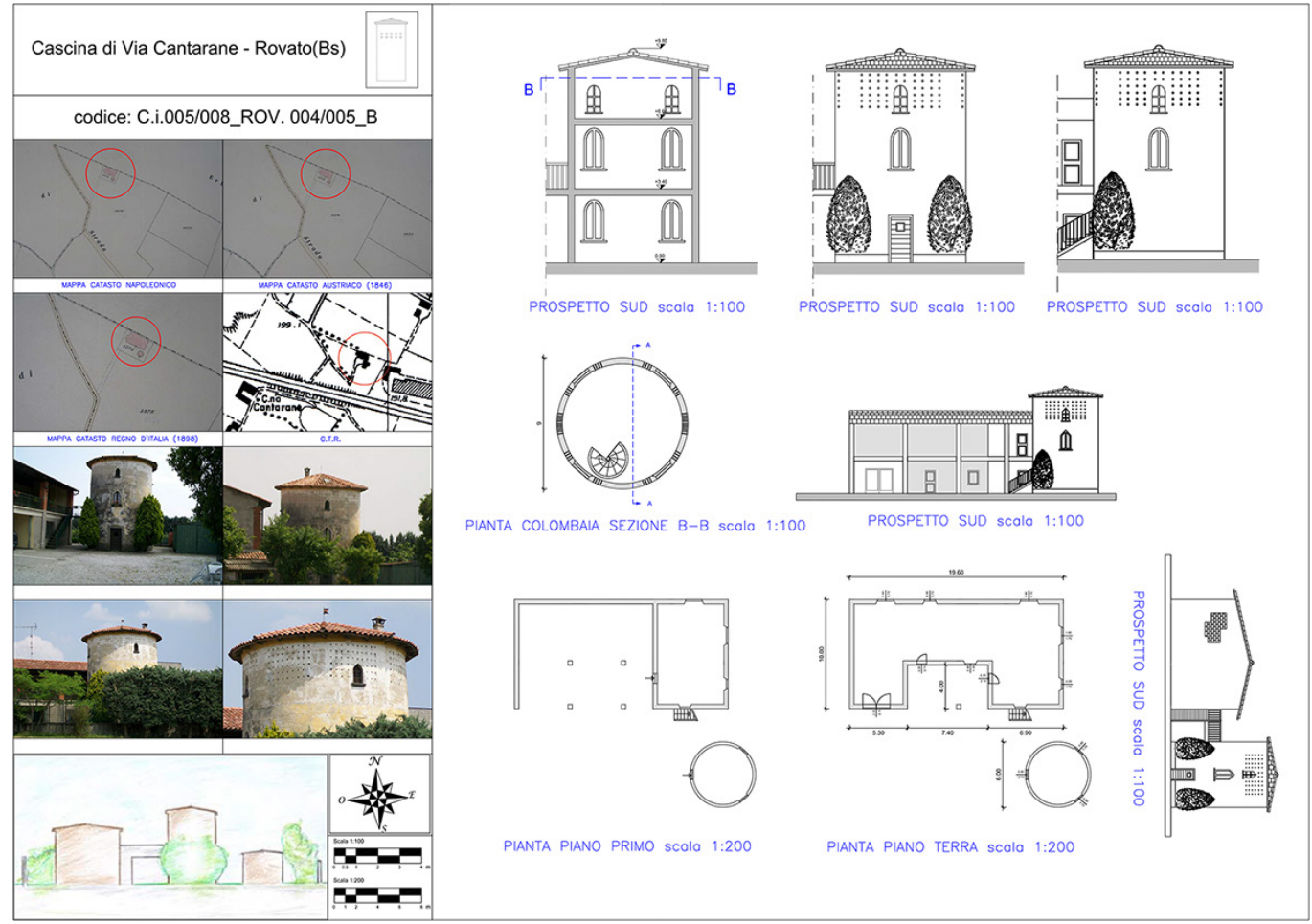


Fig. 9. Adjacent dovecote tower in Sparviere

farmhouse located in

(framicell Brusati (Bs),

(framework by L. Scaroni,

raphic elaboration by $M$.

Pontoglio Emilii).
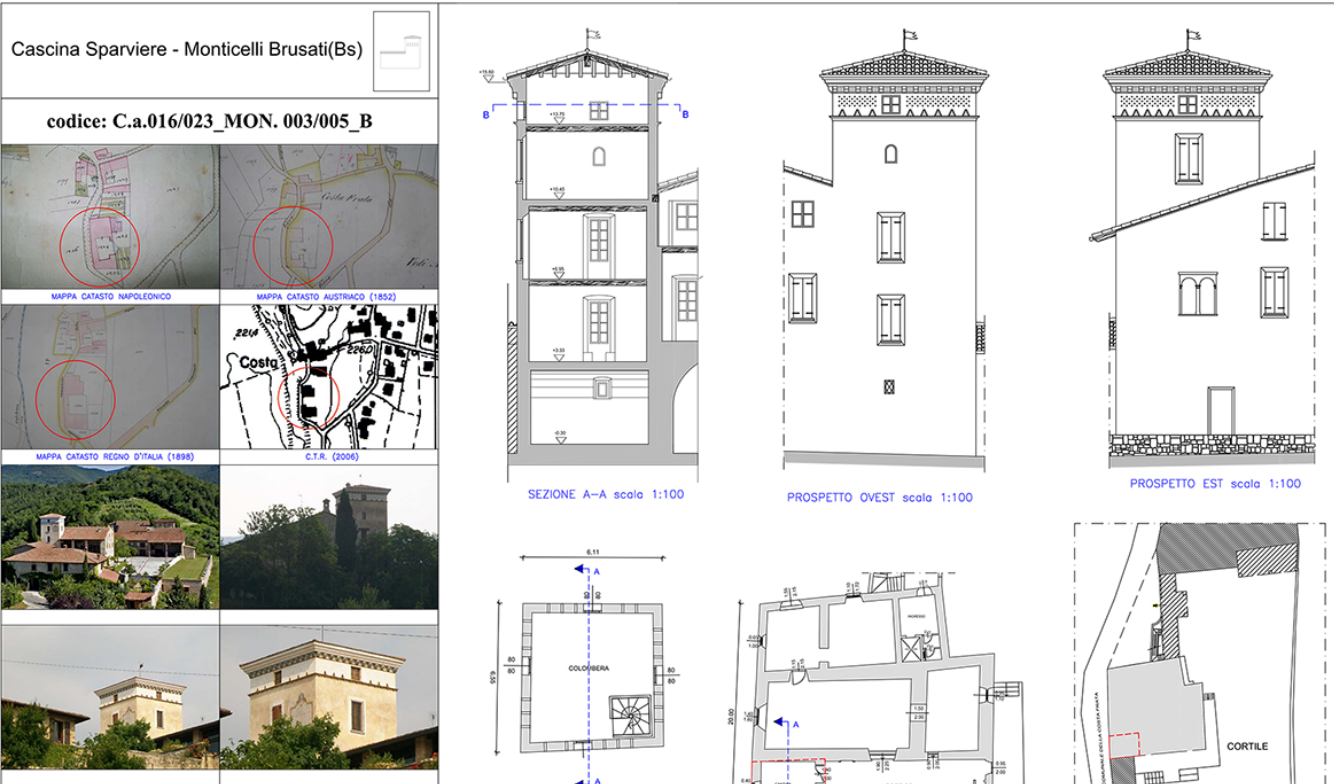

PROSPEETO EST scolo 1:100
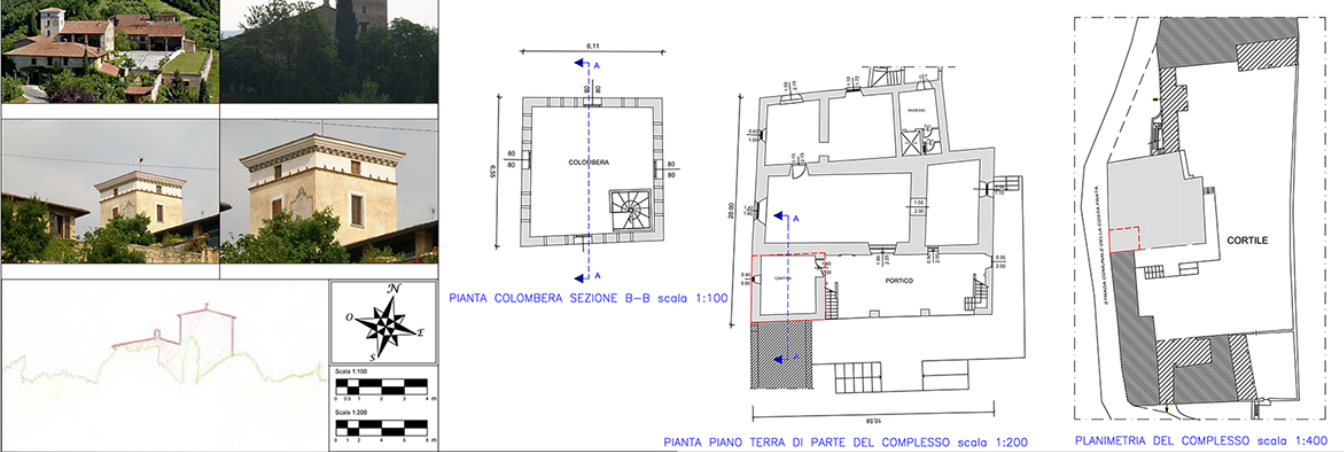

PANTA PIANO TERRA DI PARTE DEL COMPLESSO Scola -
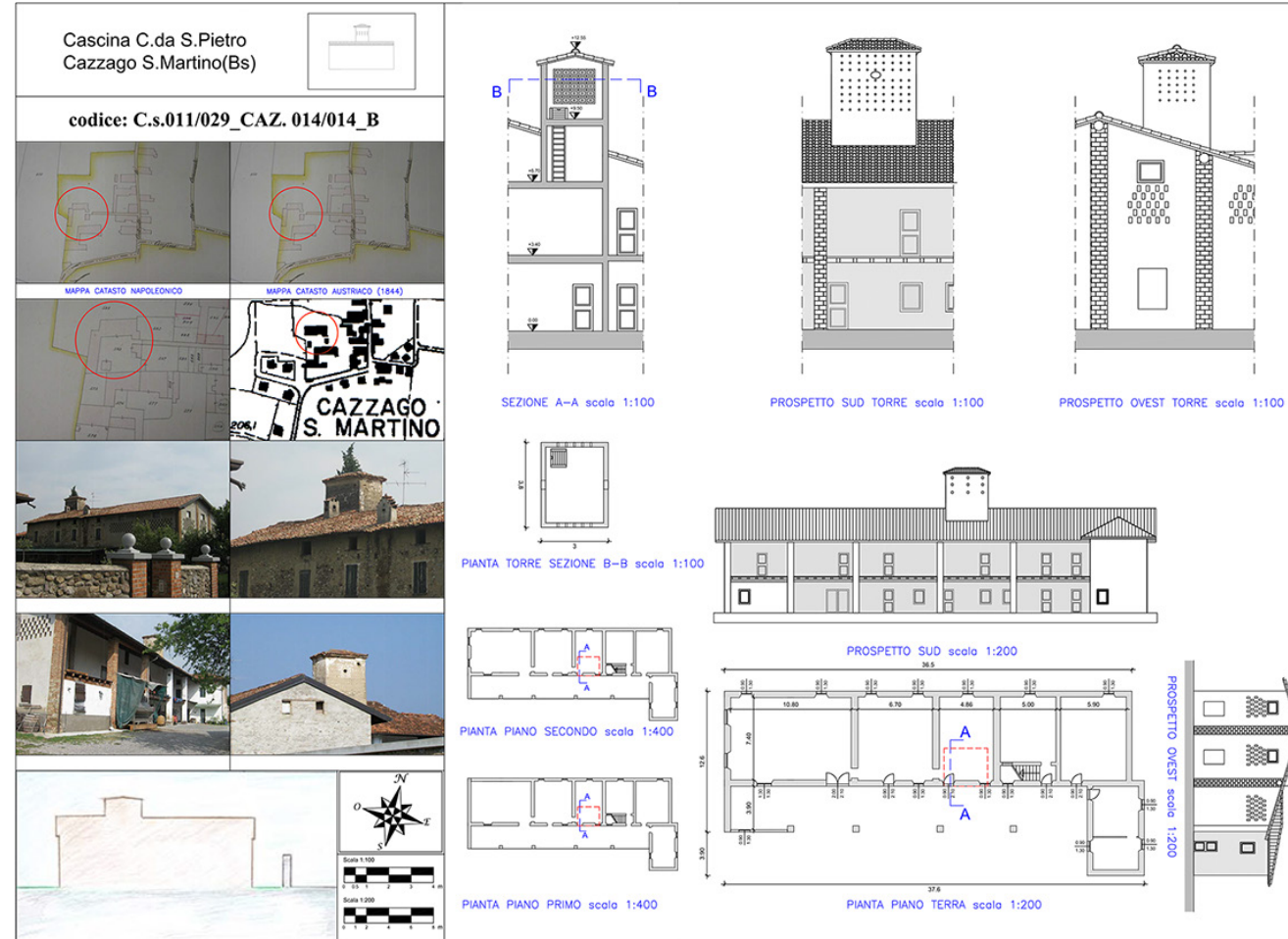

PROSPETTO SUD TORRE scalo 1:100

Fig. 10. Above dovecote tower in S. Pietro farmhouse located in

Cazzago S. Martino (Bs)

(framework by L. Scaron

graphic elaboration by $M$. Pontoglio Emilii).
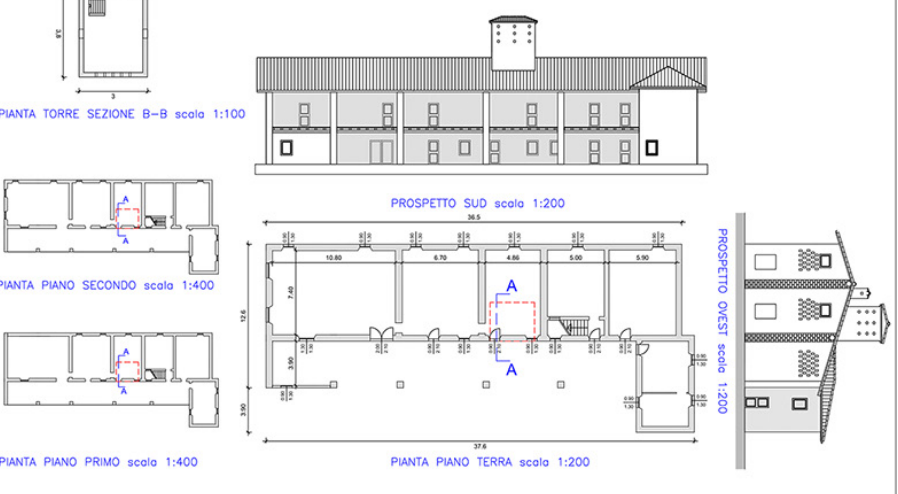


\section{Notes}

[I] Despite having shared objectives, methodologies and results of the research, it is highlighted that Passamani is the author of paragraphs I and 2; Pontoglio Emilii of 3 and 4.

[2] The theme of the dovecote in the landscape of the plain, focus of a research of the team coordinated by I. Passamani, was also studied in the degree thesis in Civil Engineering of Luca Scaroni Studio dei sistemi cascina-colombaie/passerere nel paesaggio della Franciacorta, supervisor I. Passamani, assistant supervisor M. Pontoglio Emilii, A.A. 20 I0/20I I.

[3] The theme of the dovecote in the landscape of the plain, focus of a research of the team coordinated by I. Passamani, was also studied in the degree thesis in Civil Engineering of Rudy Gatti Le torri colombere/passerere nel territorio della Bassa Bresciana lungo il corso del fiume Oglio, supervisor I. Passamani, assistant supervisor M. Pontoglio Emilii, A.A. 20I I/20 I 2.

\section{References}

AA.W. (1961). Storia di Brescia. Brescia: Morcelliana Editrice.

AA.W. (1984). Atlante della Bassa. I. Uomini, vicende, paesi dall'Oglio al Mella. Brescia: Grafo.

AA.W. (1988). Il paesaggio della pianura bresciana. Brescia: Grafo.

Agarotti Carlo (1984). La civiltà contadina nel Bresciano. Brescia: Edizioni del Moretto.

Crescenzi (de) Pietro (1605). Trattato dell'agricoltura ... Diviso in dodici libri, ne' quali distintamente si tratta delle piante, e degli animali. Firenze: appresso Cosimo Giunti.

Gallo Agostino (1775). Le venti giornate dell'agricoltura e de' piaceri della villa. Ristampa anastatica (2007). Brescia: La compagnia della Stampa.

Lechi Fausto (1973). Le dimore bresciane in cinque secoli di storia. Brescia: Edizioni di Storia Bresciana.

Massetti Eugenio (a cura di). (2000). Paserére. Roccafranca: La Compagnia della Stampa/Massetti Rodella Editori.

Paoletti Dezio, Fappani Antonio (a cura di). (20I5). Paesaggi Agrari ed Architetture Rurali nel Territorio Bresciano. Vol. I. Breno: Tipografia Camuna.

Passamani Ivana (2012). Alcune emergenze nel panorama di Cellatica: segni della religiosità e segni del lavoro. In AAVV. II senso del luogo. Paesaggi di Franciacorta e Sebino. Atti del Convegno di studi. Breno:Tipografia Camuna.

Rapaggi Antonio (1996). II passero sotto il tetto. In Atlante Bresciano, 49, 1996, p. 58-62.

Robotti Ciro (2009). Le torri colombaie nei paesaggi euromediterranei e del vicino Oriente: disegni, funzioni, simboli. A cura della Società di storia patria, Anno 127.

Rossi Gabriele (2012). Le colombaie del Salento meridionale. Rilievi e documenti. Archinauti quaderni della ricerca 44. Roma: Gangemi Editore.

Sereni Emilio (1987). Storia del paesaggio agrario italiano. Bari: Laterza.

Thouin \& Tessier ( 18 I8). Nuovo Corso completo d'Agricoltura teorica e pratica. Padova: Editore Crescini.

Tinelli Delfino (a cura di). (1996). Paesi e Paesaggi della Bassa Bresciana. Roccafranca: Desca Edizioni.

Traglia Antonio (a cura di). (1974). Marco Terenzio Varone. Opere. Torino: Unione Tipografico Editrice Torinese.

\section{Authors}

Ivana Passamani, Università degli Studi di Brescia, ivana.passamani@unibs.it

Matteo Pontoglio Emilii, Università degli Studi di Brescia, matteo.pontoglio@unibs.it

To cite this chapter. Passamani Ivana, Pontoglio Emilii Matteo (2020). Le torri colombaie nel paesaggio di pianura. Analisi tipologiche, rilievo architettonico per la conoscenza/The dovecote towers in the Po Valley landscape. Typological Analysis, Architectural Survey to Knowledge. In Arena A., Arena M., Brandolino R.G., Colistra D., Ginex G., Mediati D., Nucifora S., Raffa P. (a cura di). Connettere. Un disegno per annodare e tessere. Atti del $42^{\circ}$ Convegno Internazionale dei Docenti delle Discipline della Rappresentazione/Connecting. Drawing for weaving relationships. Proceedings of the 42th International Conference of Representation Disciplines Teachers. Milano: FrancoAngeli, pp. 255I-2570. 